\title{
Different Temperature Regimes Influenced the Quality of Broccoli Seedlings, Which Caused a Change in the Chemical Composition of Mature Heads
}

\author{
Andrzej Kalisz ${ }^{1, * \mathbb{D}}$, Joanna Gil ${ }^{1, *}$, Edward Kunicki ${ }^{1}$, Agnieszka Sękara ${ }^{1} \mathbb{D}$, Andrzej Sałata ${ }^{2}$ (D) \\ and Gianluca Caruso ${ }^{3}$
}

check for

updates

Citation: Kalisz, A.; Gil, J.; Kunicki, E.; Sẹkara, A.; Sałata, A.; Caruso, G. Different Temperature Regimes Influenced the Quality of Broccoli Seedlings, Which Caused a Change in the Chemical Composition of Mature Heads. Agronomy 2021, 11, 1806. https://doi.org/10.3390/ agronomy11091806

Academic Editor: Alain Deloire

Received: 22 July 2021

Accepted: 5 September 2021

Published: 8 September 2021

Publisher's Note: MDPI stays neutral with regard to jurisdictional claims in published maps and institutional affiliations.

Copyright: (c) 2021 by the authors. Licensee MDPI, Basel, Switzerland. This article is an open access article distributed under the terms and conditions of the Creative Commons Attribution (CC BY) license (https:/ / creativecommons.org/licenses/by/ $4.0 /)$.
1 Department of Horticulture, Faculty of Biotechnology and Horticulture, University of Agriculture in Krakow, 31-425 Krakow, Poland; edward.kunicki@urk.edu.pl (E.K.); agnieszka.sekara@urk.edu.pl (A.S.)

2 Department of Vegetable and Medicinal Plants, Faculty of Horticulture and Landscape Architecture, University of Life Sciences in Lublin, 20-950 Lublin, Poland; andrzej.salata@up.lublin.pl

3 Department of Agricultural Sciences, University of Naples Federico II, 80055 Portici, Naples, Italy; gcaruso@unina.it

* Correspondence: andrzej.kalisz@urk.edu.pl (A.K.); joanna.gil@urk.edu.pl (J.G.)
Abstract: Exposure of vegetable seedlings to lowered temperature affects their growth and the content of certain chemical constituents. Chilling activates defensive mechanisms against stress and leads to acclimatization which increases plant ability to withstand harsh field conditions. Thus, seedlings subjected to low-temperature treatment had altered metabolic pathways, and these changes can persist until harvest. We therefore assessed: (i) the direct response of broccoli seedlings to 1 week or 2 weeks at lowered temperatures $\left(6^{\circ} \mathrm{C}, 10^{\circ} \mathrm{C}, 14^{\circ} \mathrm{C}\right.$, and $18{ }^{\circ} \mathrm{C}$-control); and (ii) the long-term effects of the latter treatments on phytochemical components level in mature heads of broccoli cultivated in the field. Chilling stress decreased seedling shoot and root fresh and dry weights, plant height, number of leaves, leaf area, leaf perimeter, and leaf width. The most spectacular reductions in these parameters were observed at $6{ }^{\circ} \mathrm{C}$ and $10{ }^{\circ} \mathrm{C}$. Longer exposure to lowered temperature resulted in greater reduction in the values of morphological traits. Chilling led to reduction in L-ascorbic acid content in broccoli seedlings, while a $6{ }^{\circ} \mathrm{C}$ temperature caused an increase in soluble sugars. The highest content of dry weight, soluble sugars, and L-ascorbic acid were observed in the heads of plants exposed to $14{ }^{\circ} \mathrm{C}$; however, the content of dry weight (at $10^{\circ} \mathrm{C}$ ) and L-ascorbic acid (at $6{ }^{\circ} \mathrm{C}$ and $10^{\circ} \mathrm{C}$ ) also increased in broccoli heads in comparison with the control. Longer chilling (for 2 weeks) generally increased the content of these constituents in mature broccoli. Lower temperature $\left(6-14{ }^{\circ} \mathrm{C}\right)$ applied at seedling stage increased $\mathrm{P}$ and $\mathrm{Zn}$ contents in broccoli heads in comparison to the control, whereas plants treated with $10^{\circ} \mathrm{C}$ had more $\mathrm{K}, \mathrm{Fe}$, and, together with $6^{\circ} \mathrm{C}$ treatment, $\mathrm{Cu}$. The lowest temperature applied to the seedlings $\left(6^{\circ} \mathrm{C}\right)$ caused an increase in Mn content, while no effects of seedling chilling was noted for Ca levels. Significant linear correlations were noted and regression models were developed for the content of dry weight, soluble sugars, and L-ascorbic acid in the broccoli heads based on the chosen seedling parameters. The results show that the effect of lowered temperature to which the seedlings were subjected persists also in the further stages of plant ontogenesis, causing permanent changes in the chemical composition of mature broccoli heads.

Keywords: Brassica oleracea var. italica; chilling; plant modelling; phytochemicals; minerals

\section{Introduction}

Broccoli, which belongs to the group of important vegetable crops, is widely cultivated in the world and is rich in bioactive compounds and minerals [1-3]. Health benefits from broccoli are associated with high amounts of glucosinolates, isothiocyanates, phenolic compounds, ascorbic acid, tocopherols, carotenoids, and minerals including calcium, magnesium, sulphur, and selenium [4,5]. Phytochemicals occurring in vegetable crops 
mainly undergo genetic control and environmental conditions [5,6]. Apart from breeding strategies, agronomic methods to increase the content of bioactive components in broccoli are also being sought [1].

Low-temperature treatment of juvenile plants via acclimatization processes induces modification of genome and transcriptome what is related to changes in primary and secondary metabolism which shapes stress response of the plants $[7,8]$. These metabolites are essential for plant to survive environmental changes, including low temperature conditions. One of the most important consequences of abiotic stresses is the overaccumulation of reactive oxygen species (ROS) such as $\mathrm{O}_{2}{ }^{\bullet-}, \mathrm{H}_{2} \mathrm{O}_{2}$, and $\bullet \mathrm{OH}$ in plant cells $[9,10]$. The augmented ROS levels are sensed and restrictively controlled by ROS-scavenging systems comprised of enzymatic and non-enzymatic antioxidants, including compounds such as ascorbic acid, glutathione, phenolic acids, alkaloids, flavonoids, carotenoids, tocopherols, etc. [11]. In addition to the obvious functionality of a controlled application of stress, related to the plant acquisition of a better tolerance to abiotic stresses (crossprotection), this method can serve as a regulator of the level of many phytochemicals. Indeed, an increase in the content of antioxidants in chilled plants is associated with their response to stress stimuli $[12,13]$. The key question is whether the chilled plants can maintain a high level of bioactive components in the long-term perspective, up to harvest. Several reports describe the short-term effects of low-temperature treatments on vegetable seedlings, i.e., [14-16], but there are evidences for long-lasting chilling influence [16-19].

Thus, our main goal was to estimate the direct effects of different temperature regimes on broccoli seedlings, including changes in the morphology and production of dry weight, and to compare chemical composition of chilled plants and the control ones (grown at the optimal temperature), both at the end of the seedling production and at harvest. Our second target was to determine a stress biomarkers, whose change in seedlings would be associated with their change in mature broccoli heads.

\section{Materials and Methods}

\subsection{Plant Material and Treatments}

Seeds of broccoli (Brassica oleracea L. var. italica Plenck) cultivar Monaco $\mathrm{F}_{1}$ (Syngenta) were sown into black multi-pot trays (VEFI A/S, Drammen, Norway) with cone-shaped 96 cells per tray, each $53 \mathrm{~cm}^{3}$ in volume. Cells were filled with peat substrate (KlasmanTS2, Klasmann-Deilmann $\mathrm{GmbH}$, Geeste, Germany) and placed in the greenhouse. Temperature in the greenhouse was maintained at $24^{\circ} \mathrm{C} \pm 2{ }^{\circ} \mathrm{C}$ until emergence, when the temperature was lowered to $18 / 15{ }^{\circ} \mathrm{C} \pm 2{ }^{\circ} \mathrm{C}$ (day/night). All transplants were fertilized twice with Kristalon Zielony liquid fertilizer (18\% N, 18\% $\mathrm{P}_{2} \mathrm{O}_{5}, 18 \% \mathrm{~K}_{2} \mathrm{O}, 3 \% \mathrm{MgO}$, and 2\% S) (Yara Poland Sp. z o.o., Szczecin, Poland) at a dose of $10 \mathrm{~g} \mathrm{~L}^{-1}$ water. Before planting, the plants were divided into two main groups which were exposed for a period of 1 week or 2 weeks (experimental factor I) to the lowered temperatures: $6{ }^{\circ} \mathrm{C}, 10^{\circ} \mathrm{C}$, and $14{ }^{\circ} \mathrm{C}$ (factor II). Part of the seedlings, assigned to the control treatment, was left in the greenhouse under the conditions maintained according to the production standard for broccoli (temperature was $18 \pm 2{ }^{\circ} \mathrm{C}$ during the day and $15 \pm 2{ }^{\circ} \mathrm{C}$ at night until planting in a 14-h photoperiod during natural daylight). The seedlings were exposed to chilling in growth chambers under a 14-h photoperiod (via SunmasterLM 400W U46 CDX metal halide lamps, Venture Lighting Europe Ltd., Watford, UK) and under a ca. $300-\mu \mathrm{mol} \mathrm{m} \mathrm{m}^{-2} \mathrm{~s}^{-1}$ irradiance intensity. Relative air humidity was maintained at ca. $75 \%$ for all treatments. The aforementioned experiments were repeated three times over the years (2011-2013) with the same number of plants (200 seedlings) per each treatment. Morphological parameters and laboratory analyses of the seedlings were performed on 20 plants randomly collected from each treatment (5 seedlings per replication).

\subsection{Field Experiments}

Broccoli seedlings were planted out in the experimental field of the University of Agriculture in Krakow, located in southern Poland $\left(50^{\circ} 04^{\prime} \mathrm{N}, 19^{\circ} 51^{\prime} \mathrm{E}\right)$, in the first half of 
April (early spring), at $50 \times 45 \mathrm{~cm}$ spacing, and covered with nonwoven fleece (Agryl PP, $19 \mathrm{~g} \mathrm{~m}^{-2}$ ). According to the Köppen's classification, the climate was humid continental (Dfb). Covers were removed after about 5 weeks. The soil type was a Fluvic Cambisol (Humic), with respect to the classification of the Food and Agriculture Organization of the United Nations [20]. We performed standard cultivation practices, including fertilization, sprinkler irrigation, and plant protection, as recommended for broccoli [21]. The doses of fertilizers were calculated on the basis of soil analyses and crop requirements, achieving nutrient contents of $140 \mathrm{mg} \mathrm{N}\left(\mathrm{NH}_{4}+\mathrm{NO}_{3}\right), 60 \mathrm{mg} \mathrm{P}, 200 \mathrm{mg} \mathrm{K}, 70 \mathrm{mg} \mathrm{Mg}$, and $1500 \mathrm{mg}$ $\mathrm{Ca}$ in $1 \mathrm{~L}$ of soil.

The experiments were established according to the split-plot design, with low temperature duration being the main plot and temperature level the sub-plots, with three replications of each treatment. The single plot size was $9 \mathrm{~m}^{2}$ and was composed of 40 plants (30 plants intended for sampling), thus there were 90 plants in each treatment excluding those constituting the protective side rows. Samplings were performed by randomly selecting 20 marketable broccoli heads of market quality, which were transported immediately to the laboratory, to perform analysis of the constituents listed below. All samples were analyzed in quadruplicate. Field trials were performed for 3 years (2011-2013).

\subsection{Morphological Parameters of Broccoli Seedlings}

The height of the seedlings was measured from the base of the main shoot stem to the top of the longest leaf. All leaves longer than $1 \mathrm{~cm}$ were counted from individual plants. Then, the visually largest leaf was selected and its morphological features (area, perimeter, length, width) were determined with WinDIAS-3 Measurements System (DeltaT Devices Ltd., Cambridge, UK). The system comprised a video IDS camera pointing vertically down to an illuminated table where the detached leaf was placed and connected to a computer. After calibration, the system analyzed the colored threshold regions to measure leaf parameters.

\subsection{Fresh Weight of Broccoli Seedlings}

The fresh weight (FW) was assessed by weighing the shoots and roots of the seedlings, using a Sartorius A120S analytical balance (Sartorius AG, Goettingen, Germany). Before weighing, roots were extracted from peat substrate under tap water. Seedling sampling was performed after chilling treatment, just before planting in the field.

\subsection{Dry Weight of Broccoli Seedlings and Mature Heads}

The dry weight (DW) content was determined in the seedlings (shoots, roots) and in mature broccoli heads. Plant samples were dried at $92-95{ }^{\circ} \mathrm{C}$ until they reached constant mass, and the DW content was expressed in $\mathrm{g}$ per $100 \mathrm{~g}$ of FW. Next, the total dry weight of seedling shoots and roots was calculated and presented in $g$ per plant parts (shoots, roots).

\subsection{Soluble Sugars and L-ascorbic Acid Determination of Broccoli Seedlings and Mature Heads}

Broccoli seedlings and mature heads were sampled, as mentioned above. Soluble sugars were determined by the anthrone method, according to Yemm and Willis [22]. Briefly, plant material ( $1 \mathrm{~g}$ ) was mixed with $50 \mathrm{~mL}$ of $80 \%$ ethanol and the mixtures were boiled in $100{ }^{\circ} \mathrm{C}$. Anthrone reagent $\left(0.2 \mathrm{~g}\right.$ anthrone in $\left.100 \mathrm{~mL} \mathrm{H}_{2} \mathrm{SO}_{4}\right)$ was added in the amount of $4 \mathrm{~mL}$, and the samples were placed for $10 \mathrm{~min}$ in a water bath $\left(100{ }^{\circ} \mathrm{C}\right)$ and cooled down to room temperature. Next, the absorbance was measured at $625 \mathrm{~nm}$ using a Helios Beta spectrophotometer (Thermo Fisher Scientific Inc., Waltham, MA, USA).

L-ascorbic acid was measured by the Tillmans method [23]. Plant material (50 g) was mixed with $200 \mathrm{~mL}$ of $\mathrm{CH}_{3} \mathrm{COOH}$ and, after $30 \mathrm{~min}$, the extract was titrated with the reagent 2,6-dichlorophenolindophenol (Tillman's reagent). Excessive dye in an acidic environment gives a pink color and marks the end point of the titration. Then, the amount of Tillman's reagent used for titration was recalculated to the content of L-ascorbic acid. 


\subsection{Photosynthetic Pigments Content of Mature Broccoli Heads}

Plants were sampled, as mentioned above, and analyzed on pigments content according to the method described by Lichtenthaler and Wellburn [24]. Plant samples $(0.1 \mathrm{~g})$ were ground with $3 \mathrm{mg}$ of magnesium carbonate $\left(\mathrm{MgCO}_{3}\right)$. Chlorophyll $a$, chlorophyll $b$, and carotenoids were extracted in $80 \%(v / v)$ aqueous acetone $(25 \mathrm{~mL})$. After $0.5 \mathrm{~h}$ in the dark and filtration (filter paper POCH SA, No. 978774513, Gliwice, Poland), the absorbance was read at 663, 646, and $470 \mathrm{~nm}$, respectively, using a Helios Beta spectrophotometer. The chlorophyll and carotenoids contents were calculated using the equations described by Lichtenthaler and Wellburn [24].

\subsection{Mineral Composition of Mature Broccoli Heads}

Mineral composition of broccoli heads was determined according to the method described by Ostrowska et al. [25]. Sampled heads were washed in demineralized water, ground in a blender, dried in an oven at $70^{\circ} \mathrm{C}$, and fragmented by the colloidal mill (Retsch ZM 200, Haan, Germany). The dried material (5 g) was burnt wet at $500^{\circ} \mathrm{C}$ and the ash was dissolved in $2.5 \mathrm{~mL}$ of $20 \%$ solution $\mathrm{HNO}_{3}$. The suspension was vaporized and $2.5 \mathrm{~mL}$ of $20 \% \mathrm{HCl}$ was added and again it was vaporized. Finally, $2.5 \mathrm{~mL}$ of $20 \% \mathrm{HNO}_{3}$ was added to the precipitate; all of this was transferred to the flasks and filled with distilled water to a $25-\mathrm{mL}$ volume. The element contents $(\mathrm{K}, \mathrm{Mg}, \mathrm{Ca}, \mathrm{Fe}, \mathrm{Cu}, \mathrm{Mn}, \mathrm{Zn})$ were determined by absorption spectrometer Varian Spectr AA 20 (Palo Alto, CA, USA). Phosphorus was determined by a colorimetric method using a 1:1 mixture of ammonium methanavanadate $\mathrm{NH}_{4} \mathrm{VO}_{3}$ and ammonium molybdate $\left(\mathrm{NH}_{4}\right)_{6} \mathrm{Mo}_{7} \mathrm{O}_{24} \cdot 4 \mathrm{H}_{2} \mathrm{O}$ solutions $(10 \mathrm{~mL})$, which was added to $2.5 \mathrm{~mL}$ of sample solution. The transmittance of the samples was determined on a Helios Beta spectrophotometer at a wavelength of $460 \mathrm{~nm}$.

\subsection{Statistical Analysis}

The results were evaluated statistically based on the analysis of ANOVA in the STATISTICA program (TIBCO Software Inc., Palo Alto, CA, USA) using HSD Tukey's test to separate means into homogenous groups at $p<0.05\left(^{*}\right)$ for temperature duration (TD), temperature level $(\mathrm{TL})$, and their interaction $(\mathrm{TD} \times \mathrm{TL})$. The level of significance was also assessed at $p<0.01\left(^{* *}\right)$ and $p<0.001\left(^{* * *}\right)$. Data for each measurement represent the mean of four replications \pm standard deviation (SD). Before further analysis, data were pooled over the 3 years for greater clarity and due to similarities in plant response. Linear correlation (Descriptive Statistics module) and polynomial regression (General Regression Models module) analysis was performed to find relationships between chosen seedlings and heads traits and to developed regression equations, allowing to estimate dry weight, soluble sugars, and L-ascorbic acid content in the heads of broccoli on the basis of its contents in the chilled seedlings. No such relationships were found for chlorophyll $a$, chlorophyll $b$, and carotenoids, thus these data were not presented. Analyzes were carried out by checking the significance at $p<0.05$ and determining the linear correlation coefficient $(r)$ and, for regression models, the coefficient of determination $\left(R^{2}\right)$ and adjusted coefficient of determination $\left(R^{2}\right.$ adj. $)$.

\section{Results}

\subsection{Morphological Parameters of Broccoli Seedlings}

Morphological traits of broccoli seedlings were highly affected by temperature treatment (Table 1). The lowest height, number of leaves, leaf area, leaf perimeter, and leaf width were shown by plants exposed to $6{ }^{\circ} \mathrm{C}$ for 2 weeks, and, in the case of leaf perimeter and leaf width, no statistically significant differences were found for plants treated with $10^{\circ} \mathrm{C}$ for 2 weeks. The only difference in leaf length was observed for the plants treated with $6{ }^{\circ} \mathrm{C}$ for 1 week and $14{ }^{\circ} \mathrm{C}$ for 2 weeks. For almost all the seedling parameters assessed, higher values were found for the control, with the only exception of the leaf length, whose values were not statistically different from those relevant to the other temperature combinations. These observations were confirmed by the analysis of main effects of temperature duration: 
broccoli plants treated with the two lowest temperatures for 2 weeks were smaller than those exposed to the same temperatures for 1 week, while the control ones were the biggest. Only leaf length was not affected by temperature duration. The leaf area showed the most spectacular decrease in plants treated with the low temperature for 2 weeks, with a $32.2 \%$ lower value than the control. The effect of temperature level itself was also statistically significant. As the temperature decreased, the plant height and the number of leaves gradually decreased, with significant differences for each treatment and the greatest gap corresponding to $6{ }^{\circ} \mathrm{C}(25.3 \%$ and $21.6 \%$ lower than the control, respectively). The seedlings had the lowest leaf area and leaf perimeter at 6 and $10{ }^{\circ} \mathrm{C}$, i.e., $27.7 \%$ and $16.5 \%$ lower than the control, respectively. The control plants had the widest leaves, but no length differences compared to the other treatments.

Table 1. Effect of low-temperature treatment on morphological parameters of broccoli seedlings.

\begin{tabular}{|c|c|c|c|c|c|c|c|}
\hline $\begin{array}{c}\text { Temperature } \\
\text { Duration } \\
\text { (Weeks) }\end{array}$ & $\begin{array}{c}\text { Temperature } \\
\text { Level } \\
\left({ }^{\circ} \mathrm{C}\right)\end{array}$ & $\begin{array}{l}\text { Height } \\
\text { (cm) }\end{array}$ & $\begin{array}{l}\text { Number } \\
\text { of Leaves }\end{array}$ & $\begin{array}{l}\text { Leaf Area } \\
\left(\mathrm{cm}^{2}\right)\end{array}$ & $\begin{array}{c}\text { Leaf } \\
\text { Perimeter } \\
\text { (cm) }\end{array}$ & $\begin{array}{l}\text { Leaf Width } \\
\quad(\mathrm{cm})\end{array}$ & $\begin{array}{l}\text { Leaf Length } \\
\text { (cm) }\end{array}$ \\
\hline \multirow[t]{3}{*}{1} & 6 & $18.5 \pm 0.33 c$ & $4.3 \pm 0.06 \mathrm{~b}$ & $29.8 \pm 0.89 \mathrm{~d}$ & $39.5 \pm 1.18 b$ & $5.8 \pm 0.10 \mathrm{~d}$ & $6.9 \pm 0.14 \mathrm{a}$ \\
\hline & 10 & $18.3 \pm 0.27 c$ & $4.6 \pm 0.11 c$ & $27.5 \pm 0.47 c$ & $39.7 \pm 0.43 b$ & $5.5 \pm 0.05 \mathrm{~cd}$ & $7.1 \pm 0.13 \mathrm{ab}$ \\
\hline & 14 & $19.5 \pm 0.24 \mathrm{~d}$ & $4.8 \pm 0.06 c$ & $\begin{array}{c}28.4 \pm 0.77 \\
\mathrm{~cd}\end{array}$ & $40.2 \pm 0.90 \mathrm{~b}$ & $5.6 \pm 0.16 \mathrm{~d}$ & $7.2 \pm 0.18 \mathrm{ab}$ \\
\hline \multirow[t]{3}{*}{2} & 6 & $16.2 \pm 0.27 \mathrm{a}$ & $3.7 \pm 0.14 \mathrm{a}$ & $21.8 \pm 0.46 \mathrm{a}$ & $34.2 \pm 0.52 \mathrm{a}$ & $4.9 \pm 0.12 \mathrm{a}$ & $7.0 \pm 0.08 \mathrm{ab}$ \\
\hline & 10 & $17.0 \pm 0.20 \mathrm{~b}$ & $4.2 \pm 0.11 b$ & $23.7 \pm 0.90 \mathrm{~b}$ & $35.8 \pm 1.43 \mathrm{a}$ & $5.1 \pm 0.07 \mathrm{ab}$ & $7.1 \pm 0.24 \mathrm{ab}$ \\
\hline & 14 & $19.2 \pm 0.09 \mathrm{~d}$ & $4.6 \pm 0.08 c$ & $27.2 \pm 0.38 c$ & $39.0 \pm 0.32 b$ & $5.3 \pm 0.03 \mathrm{bc}$ & $7.4 \pm 0.09 b$ \\
\hline Control & 18 & $23.3 \pm 0.19 \mathrm{e}$ & $5.1 \pm 0.20 \mathrm{~d}$ & $35.7 \pm 1.43 \mathrm{e}$ & $44.2 \pm 1.24 \mathrm{c}$ & $6.2 \pm 0.16 \mathrm{e}$ & $7.2 \pm 0.20 \mathrm{ab}$ \\
\hline \multicolumn{8}{|c|}{ Duration (TD) (weeks) } \\
\hline \multicolumn{2}{|c|}{1} & $18.8 \pm 0.60 \mathrm{~B}$ & $4.6 \pm 0.20 \mathrm{~B}$ & $28.6 \pm 1.17 \mathrm{~B}$ & $39.8 \pm 0.90 \mathrm{~B}$ & $5.6 \pm 0.14 \mathrm{~B}$ & $7.1 \pm 0.21 \mathrm{~A}$ \\
\hline \multicolumn{2}{|c|}{2} & $17.5 \pm 1.31 \mathrm{~A}$ & $4.2 \pm 0.41 \mathrm{~A}$ & $24.2 \pm 2.42 \mathrm{~A}$ & $36.3 \pm 2.26 \mathrm{~A}$ & $5.1 \pm 0.21 \mathrm{~A}$ & $7.2 \pm 0.20 \mathrm{~A}$ \\
\hline \multicolumn{2}{|c|}{ Control } & $23.3 \pm 0.19 \mathrm{C}$ & $5.1 \pm 0.20 \mathrm{C}$ & $35.7 \pm 1.43 \mathrm{C}$ & $44.2 \pm 1.24 \mathrm{C}$ & $6.2 \pm 0.16 \mathrm{C}$ & $7.2 \pm 0.20 \mathrm{~A}$ \\
\hline \multicolumn{8}{|c|}{ Temperature $(\mathrm{TL})\left({ }^{\circ} \mathrm{C}\right)$} \\
\hline \multicolumn{2}{|c|}{6} & $17.4 \pm 1.23 \mathrm{~A}$ & $4.0 \pm 0.36 \mathrm{~A}$ & $25.8 \pm 4.35 \mathrm{~A}$ & $36.9 \pm 2.97 \mathrm{~A}$ & $5.4 \pm 0.49 \mathrm{~A}$ & $7.0 \pm 0.14 \mathrm{~A}$ \\
\hline \multicolumn{2}{|c|}{10} & $17.7 \pm 0.75 \mathrm{~B}$ & $4.4 \pm 0.25 \mathrm{~B}$ & $25.6 \pm 2.16 \mathrm{~A}$ & $37.8 \pm 2.11 \mathrm{~A}$ & $5.3 \pm 0.27 \mathrm{~A}$ & $7.1 \pm 0.18 \mathrm{AB}$ \\
\hline \multicolumn{2}{|c|}{14} & $19.4 \pm 0.25 C$ & $4.7 \pm 0.10 \mathrm{C}$ & $27.8 \pm 1.00 \mathrm{~B}$ & $39.6 \pm 0.87 \mathrm{~B}$ & $5.5 \pm 0.18 \mathrm{~A}$ & $7.3 \pm 0.15 \mathrm{~B}$ \\
\hline \multicolumn{2}{|c|}{ Control } & $23.3 \pm 0.19 \mathrm{D}$ & $5.1 \pm 0.20 \mathrm{D}$ & $35.7 \pm 1.43 \mathrm{C}$ & $44.2 \pm 1.24 \mathrm{C}$ & $6.2 \pm 0.16 \mathrm{~B}$ & $7.2 \pm 0.20 \mathrm{AB}$ \\
\hline \multicolumn{8}{|c|}{ Significance } \\
\hline \multicolumn{2}{|c|}{$\mathrm{TD}$} & $* * *$ & $* * *$ & $* * *$ & $* * *$ & $* * *$ & ns \\
\hline \multicolumn{2}{|c|}{$\mathrm{TL}$} & $* * *$ & $* * *$ & $* * *$ & $* * *$ & $* * *$ & $* *$ \\
\hline \multicolumn{2}{|c|}{$\mathrm{TD} \times \mathrm{TL}$} & $* * *$ & $* * *$ & $* * *$ & $* * *$ & $* * *$ & $* *$ \\
\hline
\end{tabular}

Within each column, mean values followed by different capital letters with regard to main effects (TD, TL) and lowercase letters for interactions (TD $\times \mathrm{TL}$ ), are significantly different at $p \leq 0.05$ according to Tukey's HSD test. Level of significance: ${ }^{* *} p \leq 0.01$; ${ }^{* * *} p \leq 0.001$; ns-not significant. Data are means of four replications \pm SD.

\subsection{Fresh and Dry Weight of Broccoli Seedlings}

All temperature regimes decreased shoot fresh weight (FW) by $48.8 \%\left(6^{\circ} \mathrm{C} / 2\right.$ weeks) to $21.4 \%\left(14^{\circ} \mathrm{C} / 1\right.$ week) in comparison to the control (Table 2). Broccoli seedlings treated with $14^{\circ} \mathrm{C}$ for 2 weeks had the lowest content of dry weight (DW, expressed in g per $100 \mathrm{~g}$ FW) while the highest content was found in the seedlings exposed to $6{ }^{\circ} \mathrm{C}$ for 2 weeks. The total shoot dry weight was the lowest under low-temperature treatments, as compared to the control. The most spectacular decrease was found for plants treated with $6{ }^{\circ} \mathrm{C}$ and $10{ }^{\circ} \mathrm{C}$ for 2 weeks (a decrease by $42.7 \%$ and $44.7 \%$ in comparison to the control, respectively). In the aforementioned treatments, root fresh weight was the lowest, by $56.0 \%$ and $62.0 \%$ in comparison to the control, respectively. Temperatures of $10{ }^{\circ} \mathrm{C}$ and $14{ }^{\circ} \mathrm{C}$ maintained for 1 weeks in the surrounding of seedlings did not cause reductions of root fresh weight. The lowest root dry weight was found for seedlings subjected to $10^{\circ} \mathrm{C}$ for 1 week, while the highest content of DW occurred in broccoli grown at $10^{\circ} \mathrm{C}$ for 2 weeks, with differences reaching $21.7 \%(\downarrow)$ and $20.8 \%(\uparrow)$, respectively, in comparison to the control. All temperature 
regimes decreased the total root DW in comparison to the control, at the highest extent $(53.2 \%)$ in the case of $10{ }^{\circ} \mathrm{C} / 2$ weeks. Results of main effects analysis showed generally the lowest shoot and root FW and DW in plants treated with the low temperature for 2 weeks, representing significantly higher values in plants treated with the same temperatures for 1 week, and the highest fresh and dry weight usually in control plants. Only shoot DW content of control plants did not significantly differ from that recorded in plants treated for 1 week. Furthermore, the percentage content of root DW of control broccoli was lower than that of plants treated with the low temperatures for 2 weeks. The effect of temperature level itself was also statistically significant. The fresh weight of shoot and root was the highest in control seedlings, lower in plants treated with $14^{\circ} \mathrm{C}$, and the lowest in plants exposed to $6^{\circ} \mathrm{C}$ and $10{ }^{\circ} \mathrm{C}$. A higher content of DW was observed at $6{ }^{\circ} \mathrm{C}$ (by $0.89 \mathrm{~g} 100 \mathrm{~g}^{-1}$

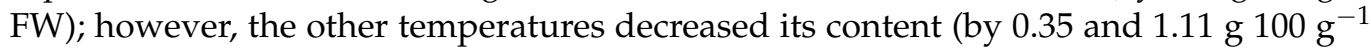
FW, respectively) in comparison to the control plants. Only a similar trend was found for root DW, not confirmed statistically. Total shoot DW and total root DW was the highest in control seedlings, while all temperatures decreased DW contents.

Table 2. Effect of low-temperature treatment on fresh weight and dry weight of broccoli seedlings.

\begin{tabular}{|c|c|c|c|c|c|c|c|}
\hline $\begin{array}{l}\text { Temperature } \\
\text { Duration } \\
\text { (Weeks) }\end{array}$ & $\begin{array}{c}\text { Temperature } \\
\text { Level } \\
\left({ }^{\circ} \mathrm{C}\right)\end{array}$ & $\begin{array}{l}\text { Shoot Fresh } \\
\text { Weight } \\
\text { (g per Plant) }\end{array}$ & $\begin{array}{c}\text { Shoot Dry } \\
\text { Weight } \\
\left.\text { (g } 100 \mathrm{~g}^{-1} \mathrm{FW}\right)\end{array}$ & $\begin{array}{c}\text { Total Shoot Dry } \\
\text { Weight } \\
\text { (g per Plant) }\end{array}$ & $\begin{array}{l}\text { Root Fresh } \\
\text { Weight } \\
\text { (g per Plant) }\end{array}$ & $\begin{array}{c}\text { Root Dry } \\
\text { Weight } \\
\left.\text { (g } 100 \mathrm{~g}^{-1} \mathrm{FW}\right)\end{array}$ & $\begin{array}{c}\text { Total Root Dry } \\
\text { Weight } \\
\text { (g per Plant) }\end{array}$ \\
\hline \multirow[t]{3}{*}{1} & 6 & $3.77 \pm 0.268 b$ & $10.72 \pm 0.046 \mathrm{~d}$ & $0.404 \pm 0.0271 c$ & $0.38 \pm 0.025 c$ & $12.63 \pm 0.640 \mathrm{bc}$ & $0.048 \pm 0.0055 b$ \\
\hline & 10 & $3.66 \pm 0.521 b$ & $10.35 \pm 0.166 \mathrm{c}$ & $0.379 \pm 0.0513 b c$ & $0.47 \pm 0.043 \mathrm{~d}$ & $9.77 \pm 0.170 \mathrm{a}$ & $0.046 \pm 0.0044 b$ \\
\hline & 14 & $3.85 \pm 0.145 b$ & $9.32 \pm 0.085 b$ & $0.359 \pm 0.0127 b c$ & $0.48 \pm 0.022 \mathrm{~d}$ & $12.14 \pm 0.203 \mathrm{~b}$ & $0.058 \pm 0.0030 \mathrm{c}$ \\
\hline \multirow[t]{3}{*}{2} & 6 & $2.51 \pm 0.183 a$ & $11.36 \pm 0.090 \mathrm{e}$ & $0.285 \pm 0.0213 \mathrm{a}$ & $0.22 \pm 0.007 \mathrm{a}$ & $13.95 \pm 0.869 \mathrm{~cd}$ & $0.031 \pm 0.0023 \mathrm{a}$ \\
\hline & 10 & $2.97 \pm 0.100 \mathrm{a}$ & $9.25 \pm 0.061 b$ & $0.275 \pm 0.0100 \mathrm{a}$ & $0.19 \pm 0.017 \mathrm{a}$ & $15.07 \pm 0.926 \mathrm{~d}$ & $0.029 \pm 0.0029 \mathrm{a}$ \\
\hline & 14 & $3.71 \pm 0.178 \mathrm{~b}$ & $8.75 \pm 0.059 \mathrm{a}$ & $0.325 \pm 0.0169 \mathrm{ab}$ & $0.30 \pm 0.028 \mathrm{~b}$ & $11.54 \pm 0.472 \mathrm{~b}$ & $0.035 \pm 0.0030 \mathrm{a}$ \\
\hline Control & 18 & $4.90 \pm 0.038 c$ & $10.15 \pm 0.083 c$ & $0.497 \pm 0.0012 \mathrm{~d}$ & $0.50 \pm 0.032 \mathrm{~d}$ & $12.48 \pm 0.378 b$ & $0.062 \pm 0.0048 \mathrm{c}$ \\
\hline \multicolumn{8}{|c|}{ Duration (TD) (weeks) } \\
\hline \multicolumn{2}{|c|}{1} & $3.76 \pm 0.326 \mathrm{~B}$ & $10.13 \pm 0.627 \mathrm{~B}$ & $0.381 \pm 0.0366 \mathrm{~B}$ & $0.44 \pm 0.056 \mathrm{~B}$ & $11.51 \pm 1.355 \mathrm{~A}$ & $0.051 \pm 0.0069 \mathrm{~B}$ \\
\hline \multicolumn{2}{|c|}{2} & $3.06 \pm 0.537 \mathrm{~A}$ & $9.79 \pm 1.181 \mathrm{~A}$ & $0.295 \pm 0.0271 \mathrm{~A}$ & $0.24 \pm 0.052 \mathrm{~A}$ & $13.52 \pm 1.694 \mathrm{C}$ & $0.032 \pm 0.0036 \mathrm{~A}$ \\
\hline \multicolumn{2}{|c|}{ Control } & $4.90 \pm 0.038 \mathrm{C}$ & $10.15 \pm 0.083 \mathrm{~B}$ & $0.497 \pm 0.0012 \mathrm{C}$ & $0.50 \pm 0.032 \mathrm{C}$ & $12.48 \pm 0.378 \mathrm{~B}$ & $0.062 \pm 0.0048 \mathrm{C}$ \\
\hline \multicolumn{8}{|c|}{ Temperature $(\mathrm{TL})\left({ }^{\circ} \mathrm{C}\right)$} \\
\hline \multicolumn{2}{|c|}{6} & $3.14 \pm 0.708 \mathrm{~A}$ & $11.04 \pm 0.348 \mathrm{D}$ & $0.346 \pm 0.0676 \mathrm{~A}$ & $0.30 \pm 0.087 \mathrm{~A}$ & $13.29 \pm 0.997 \mathrm{~B}$ & $0.040 \pm 0.0101 \mathrm{~A}$ \\
\hline \multicolumn{2}{|c|}{10} & $3.32 \pm 0.508 \mathrm{~A}$ & $9.80 \pm 0.597 \mathrm{~B}$ & $0.327 \pm 0.0652 \mathrm{~A}$ & $0.33 \pm 0.150 \mathrm{~A}$ & $12.42 \pm 2.898 \mathrm{~A}$ & $0.038 \pm 0.0096 \mathrm{~A}$ \\
\hline \multicolumn{2}{|c|}{14} & $3.78 \pm 0.169 \mathrm{~B}$ & $9.04 \pm 0.311 \mathrm{~A}$ & $0.342 \pm 0.0230 \mathrm{~A}$ & $0.39 \pm 0.097 \mathrm{~B}$ & $11.84 \pm 0.467 \mathrm{~A}$ & $0.047 \pm 0.0128 \mathrm{~B}$ \\
\hline \multicolumn{2}{|c|}{ Control } & $4.90 \pm 0.038 \mathrm{C}$ & $10.15 \pm 0.083 C$ & $0.497 \pm 0.0012 \mathrm{~B}$ & $0.50 \pm 0.032 \mathrm{C}$ & $12.48 \pm 0.378 \mathrm{AB}$ & $0.062 \pm 0.0048 \mathrm{C}$ \\
\hline \multicolumn{8}{|c|}{ Significance } \\
\hline \multicolumn{2}{|c|}{$\mathrm{TD}$} & $* * *$ & $* * *$ & $* * *$ & $* * *$ & $* * *$ & $* * *$ \\
\hline \multicolumn{2}{|c|}{$\mathrm{TL}$} & $* * *$ & $* * *$ & $* * *$ & $* * *$ & $* * *$ & $* * *$ \\
\hline \multicolumn{2}{|c|}{$\mathrm{TD} \times \mathrm{TL}$} & $* * *$ & $* * *$ & $* * *$ & $* * *$ & $* * *$ & $* * *$ \\
\hline
\end{tabular}

Within each column, mean values followed by different capital letters with regard to main effect (TD, TL) and lowercase letters for interactions (TD $\times \mathrm{TL}$ ), are significantly different at $p \leq 0.05$ according to Tukey's HSD test. Level of significance: *** $p \leq 0.001$. Data are means of four replications \pm SD.

\subsection{Soluble Sugars and L-Ascorbic Acid of Broccoli Seedlings and Mature Heads}

The highest content of soluble sugars was recorded in broccoli seedlings exposed to $6{ }^{\circ} \mathrm{C}$ for 1 week, while $10{ }^{\circ} \mathrm{C}$ maintained for 2 weeks caused the highest decrease in their content, with differences reaching $59.8 \%(\uparrow)$ and $58.8 \%(\downarrow)$, respectively, compared to the control plants (Figure 1a). Generally, plants treated with different low temperatures for 1 week showed the highest level of soluble sugars (SS), while the lowest content of SS was detected in plants associated to 2 weeks of treatment. The temperature at $6{ }^{\circ} \mathrm{C}$ level caused the highest increase in SS content (by 26.5\%), while the $14^{\circ} \mathrm{C}$-treated plants had the lowest concentration of these compounds (by $41.7 \%$ ), when compared to the control. 


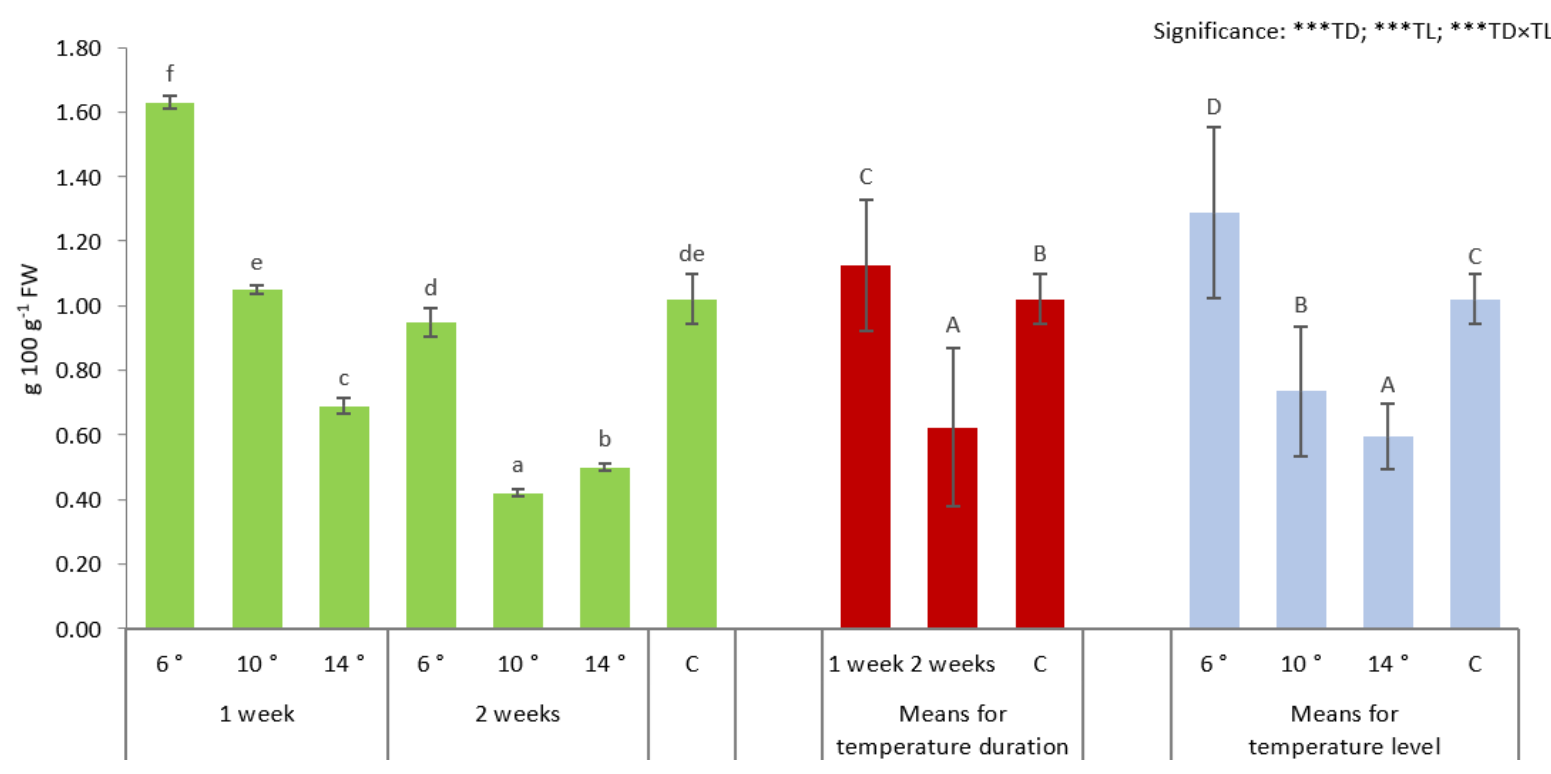

(a)

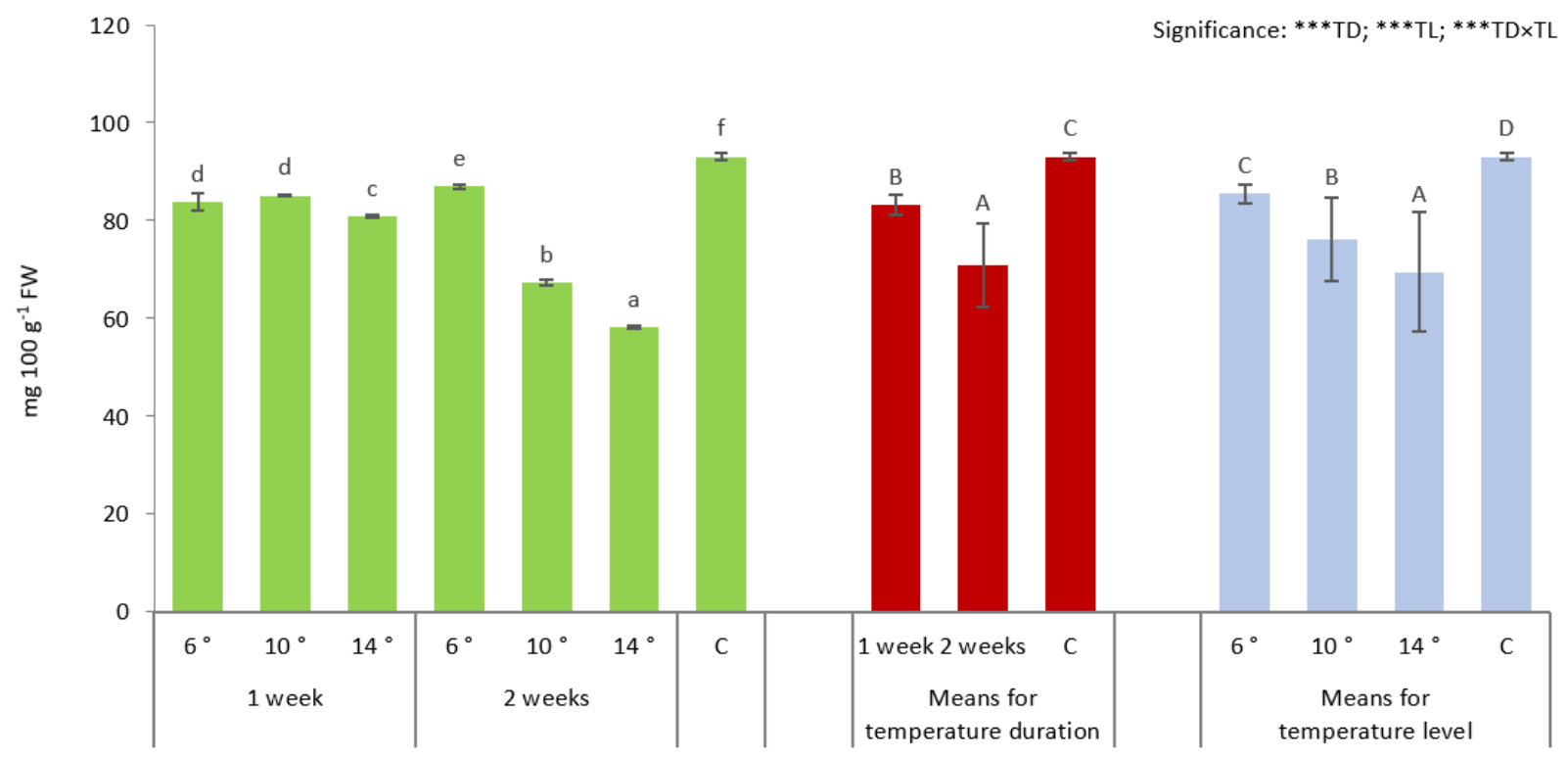

(b)

Figure 1. Content of soluble sugars (a) and L-ascorbic acid (b) of broccoli seedlings depending on the temperature duration (TD: 1 week and 2 weeks) and level (TL: $6{ }^{\circ} \mathrm{C}, 10{ }^{\circ} \mathrm{C}, 14^{\circ} \mathrm{C}, 18^{\circ} \mathrm{C}$-control, C). Means followed by different capital letters with regard to temperature duration and temperature level effects (red and blue columns, respectively), and lowercase letters for interactions (TD $\times$ TL; green columns) are significantly different at $p \leq 0.05$, according to Tukey's honestly significant difference test. Level of significance: ${ }^{* *} p \leq 0.001$. Data are means of four replications $\pm \mathrm{SD}$ (error bars).

All temperature regimes caused a decrease in L-ascorbic acid contents, the most remarkable corresponding to $14{ }^{\circ} \mathrm{C} / 2$ weeks (by $37.5 \%$ ) when compared to the control plants (Figure 1b). Seedlings treated with $10^{\circ} \mathrm{C}$ and $14{ }^{\circ} \mathrm{C}$ for 2 weeks had lower content of L-ascorbic acid than plants treated for 1 weeks with the same temperatures, while $6{ }^{\circ} \mathrm{C} / 2$ weeks treatment increased level of L-ascorbic acid when compared to $6{ }^{\circ} \mathrm{C}$ for 1 -week treatment. Generally, the low-temperature treatments for 1 and 2 weeks decreased the level of L-ascorbic acid (by $10.5 \%$ and $23.9 \%$, respectively). Taking into account the effect of the temperature level, a decrease in the content of L-ascorbic acid should be 
noted, with the most spectacular change noted at $14{ }^{\circ} \mathrm{C}$ (by $25.3 \%$ as compared to the control plants).

No significant differences were found in soluble sugars (SS) between control heads and plants previously treated with 6,10 , and $14{ }^{\circ} \mathrm{C}$ for 1 week (Table 3 ). However, plants cultivated from seedling exposed to 6,10 , and $14^{\circ} \mathrm{C}$ for 2 weeks had significantly higher SS content than control heads, especially when $14{ }^{\circ} \mathrm{C}$ temperature was used. Only plants chilled at $6{ }^{\circ} \mathrm{C}$ and $10{ }^{\circ} \mathrm{C}$ for 1 week had lower content of L-ascorbic acid in the mature heads than control broccoli, whereas other treatments caused an increase in the level of this phytochemical, at the highest extent under $14{ }^{\circ} \mathrm{C} / 2$ weeks (by $13.4 \%$ compared to the control). Considering the effect of chilling duration, significantly higher concentrations of soluble sugars and L-ascorbic acid were found in broccoli heads when seedlings had been treated with low temperature for 2 weeks. On the other hand, treatment of seedlings with low temperature for 1 week decreased the accumulation of these constituents. Generally, after seedlings were subjected to $14^{\circ} \mathrm{C}$, the level of SS and L-ascorbic acid increased considerably in comparison to control heads (by $10.7 \%$ and $8.0 \%$, respectively). Treatments with 6 and $10^{\circ} \mathrm{C}$ also significantly elevated the level of L-ascorbic acid in mature broccoli heads when compared to the control plants.

Table 3. Effect of low-temperature treatment of the seedlings on soluble sugars ( $\left.\mathrm{g} 100 \mathrm{~g}^{-1} \mathrm{FW}\right)$ and L-ascorbic acid (mg $100 \mathrm{~g}^{-1} \mathrm{FW}$ ) contents of broccoli heads.

\begin{tabular}{|c|c|c|c|}
\hline $\begin{array}{c}\text { Temperature } \\
\text { Duration } \\
\text { (Weeks) }\end{array}$ & $\begin{array}{c}\text { Temperature Level } \\
\left({ }^{\circ} \mathrm{C}\right)\end{array}$ & $\begin{array}{l}\text { Soluble } \\
\text { Sugars }\end{array}$ & $\begin{array}{l}\text { L-Ascorbic } \\
\text { Acid }\end{array}$ \\
\hline \multirow[t]{3}{*}{1} & 6 & $1.95 \pm 0.046 \mathrm{a}$ & $48.68 \pm 0.200 \mathrm{~b}$ \\
\hline & 10 & $1.92 \pm 0.038 \mathrm{a}$ & $46.82 \pm 0.257 \mathrm{a}$ \\
\hline & 14 & $1.94 \pm 0.034 \mathrm{a}$ & $50.74 \pm 0.321 \mathrm{~d}$ \\
\hline \multirow[t]{3}{*}{2} & 6 & $2.15 \pm 0.036 b$ & $53.42 \pm 0.006 \mathrm{e}$ \\
\hline & 10 & $2.17 \pm 0.034 \mathrm{~b}$ & $55.42 \pm 0.349 \mathrm{f}$ \\
\hline & 14 & $2.46 \pm 0.045 c$ & $56.13 \pm 0.239 \mathrm{~g}$ \\
\hline Control & 18 & $1.99 \pm 0.008 \mathrm{a}$ & $49.51 \pm 0.054 \mathrm{c}$ \\
\hline \multicolumn{4}{|c|}{ Duration (TD) (weeks) } \\
\hline \multicolumn{2}{|c|}{1} & $1.94 \pm 0.038 \mathrm{~A}$ & $48.75 \pm 1.687 \mathrm{~A}$ \\
\hline \multicolumn{2}{|c|}{2} & $2.26 \pm 0.151 \mathrm{C}$ & $54.99 \pm 1.222 \mathrm{C}$ \\
\hline \multicolumn{2}{|c|}{ Control } & $1.99 \pm 0.008 \mathrm{~B}$ & $49.51 \pm 0.054 \mathrm{~B}$ \\
\hline \multicolumn{4}{|c|}{ Temperature $(\mathrm{TL})\left({ }^{\circ} \mathrm{C}\right)$} \\
\hline \multicolumn{2}{|c|}{6} & $2.05 \pm 0.115 \mathrm{~A}$ & $51.05 \pm 2.536 \mathrm{~B}$ \\
\hline \multicolumn{2}{|c|}{10} & $2.05 \pm 0.139 \mathrm{~A}$ & $51.12 \pm 4.604 \mathrm{~B}$ \\
\hline \multicolumn{2}{|c|}{14} & $2.20 \pm 0.279 \mathrm{~B}$ & $53.44 \pm 2.896 \mathrm{C}$ \\
\hline \multicolumn{2}{|c|}{ Control } & $1.99 \pm 0.008 \mathrm{~A}$ & $49.51 \pm 0.054 \mathrm{~A}$ \\
\hline \multicolumn{4}{|c|}{ Significance } \\
\hline \multicolumn{2}{|c|}{ TD } & $* * *$ & $* * *$ \\
\hline \multicolumn{2}{|c|}{$\mathrm{TL}$} & $* * *$ & $* * *$ \\
\hline \multicolumn{2}{|c|}{$\mathrm{TD} \times \mathrm{TL}$} & $* * *$ & $* * *$ \\
\hline
\end{tabular}

\subsection{Dry Weight and Photosynthetic Pigments Content of Fully Mature Broccoli Heads}

The highest dry weight content of broccoli heads was observed in plants previously chilled for 2 weeks at $6^{\circ} \mathrm{C}, 10{ }^{\circ} \mathrm{C}$, and $14^{\circ} \mathrm{C}$ (Table 4). Plants subjected to such temperatures for 1 week showed a lower content of DW in broccoli heads, compared to the control plants. There were no spectacular changes in chlorophyll $a$ and chlorophyll $b$ level due to seedlings chilling. Only plants chilled at seedling stage at $10{ }^{\circ} \mathrm{C}$ for 1 weeks had lower contents of these pigments, by $13.0 \%$ and $13.9 \%$ respectively, compared to the control. No effects of temperature duration $\times$ temperature level were found for carotenoids levels in mature heads of broccoli. Considering the effect of chilling duration, significantly lower levels of 
dry weight, chlorophyll $a$, and chlorophyll $b$ in broccoli heads were noticed when seedlings had been treated with low temperature for 1 week. On the other hand, treatment of seedlings with low temperature for 2 weeks caused higher accumulation of dry weight in the treated heads than in the control plants, with no significant effects on chlorophylls and carotenoids. Temperature level itself also affected some contituents in broccoli heads. The highest content of dry weight was shown in the heads of broccoli cultivated from seedlings exposed to $14^{\circ} \mathrm{C}$; however, the $10^{\circ} \mathrm{C}$ treatment also caused an increase in dry weight compared to the control. No significant effects of chilling temperature were noticed for chlorophyll $a$ and carotenoids concentration in the heads; however, the chlorophyll $b$ content of plants exposed to $10{ }^{\circ} \mathrm{C}$ at seedling stage decreased finally in comparison to the control broccoli.

Table 4. Effect of low-temperature treatment of the seedlings on dry weight ( $\mathrm{g} 100 \mathrm{~g}^{-1} \mathrm{FW}$ ), chlorophylls, and carotenoids (mg $\left.100 \mathrm{~g}^{-1} \mathrm{FW}\right)$ contents of broccoli heads.

\begin{tabular}{|c|c|c|c|c|c|}
\hline $\begin{array}{l}\text { Temperature } \\
\text { Duration } \\
\text { (Weeks) }\end{array}$ & $\begin{array}{c}\text { Temperature } \\
\text { Level } \\
\left({ }^{\circ} \mathrm{C}\right)\end{array}$ & $\begin{array}{c}\text { Dry } \\
\text { Weight }\end{array}$ & $\begin{array}{c}\text { Chlorophyll } \\
a\end{array}$ & $\begin{array}{c}\text { Chlorophyll } \\
b\end{array}$ & Carotenoids \\
\hline \multirow[t]{3}{*}{1} & 6 & $8.56 \pm 0.034 \mathrm{a}$ & $5.73 \pm 0.319 b$ & $3.37 \pm 0.126 \mathrm{~b}$ & $0.78 \pm 0.136 \mathrm{a}$ \\
\hline & 10 & $8.70 \pm 0.031 \mathrm{~b}$ & $5.00 \pm 0.032 \mathrm{a}$ & $2.86 \pm 0.049 \mathrm{a}$ & $0.66 \pm 0.023 a$ \\
\hline & 14 & $8.66 \pm 0.056 \mathrm{~b}$ & $5.34 \pm 0.222 \mathrm{ab}$ & $3.15 \pm 0.125 b$ & $0.71 \pm 0.102 \mathrm{a}$ \\
\hline \multirow[t]{3}{*}{2} & 6 & $8.96 \pm 0.032 \mathrm{~d}$ & $5.46 \pm 0.241 \mathrm{ab}$ & $3.13 \pm 0.144 \mathrm{ab}$ & $0.77 \pm 0.027 \mathrm{a}$ \\
\hline & 10 & $9.21 \pm 0.026 \mathrm{e}$ & $5.79 \pm 0.088 \mathrm{~b}$ & $3.26 \pm 0.118 b$ & $0.80 \pm 0.030 \mathrm{a}$ \\
\hline & 14 & $9.72 \pm 0.031 \mathrm{f}$ & $5.65 \pm 0.238 b$ & $3.20 \pm 0.112 b$ & $0.78 \pm 0.095 a$ \\
\hline Control & 18 & $8.82 \pm 0.021 c$ & $5.75 \pm 0.255 \mathrm{~b}$ & $3.32 \pm 0.176 \mathrm{~b}$ & $0.71 \pm 0.033 \mathrm{a}$ \\
\hline \multicolumn{6}{|c|}{ Duration (TD) (weeks) } \\
\hline \multicolumn{2}{|c|}{1} & $8.64 \pm 0.072 \mathrm{~A}$ & $5.36 \pm 0.371 \mathrm{~A}$ & $3.13 \pm 0.238 \mathrm{~A}$ & $0.72 \pm 0.103 \mathrm{~A}$ \\
\hline \multicolumn{2}{|c|}{2} & $9.30 \pm 0.331 \mathrm{C}$ & $5.63 \pm 0.231 \mathrm{~B}$ & $3.20 \pm 0.126 \mathrm{AB}$ & $0.78 \pm 0.056 \mathrm{~A}$ \\
\hline \multicolumn{2}{|c|}{ Control } & $8.82 \pm 0.021 \mathrm{~B}$ & $5.75 \pm 0.255 \mathrm{~B}$ & $3.32 \pm 0.176 \mathrm{~B}$ & $0.71 \pm 0.033 \mathrm{~A}$ \\
\hline \multicolumn{6}{|c|}{ Temperature $(\mathrm{TL})\left({ }^{\circ} \mathrm{C}\right)$} \\
\hline \multicolumn{2}{|c|}{6} & $8.76 \pm 0.217 \mathrm{~A}$ & $5.60 \pm 0.298 \mathrm{~A}$ & $3.25 \pm 0.179 \mathrm{~B}$ & $0.78 \pm 0.091 \mathrm{~A}$ \\
\hline \multicolumn{2}{|c|}{10} & $8.96 \pm 0.275 \mathrm{~B}$ & $5.40 \pm 0.427 \mathrm{~A}$ & $3.06 \pm 0.230 \mathrm{~A}$ & $0.73 \pm 0.078 \mathrm{~A}$ \\
\hline \multicolumn{2}{|c|}{14} & $9.19 \pm 0.570 \mathrm{C}$ & $5.50 \pm 0.270 \mathrm{~A}$ & $3.18 \pm 0.113 \mathrm{AB}$ & $0.75 \pm 0.100 \mathrm{~A}$ \\
\hline \multicolumn{2}{|c|}{ Control } & $8.82 \pm 0.021 \mathrm{~A}$ & $5.75 \pm 0.255 \mathrm{~A}$ & $3.32 \pm 0.176 \mathrm{~B}$ & $0.71 \pm 0.033 \mathrm{~A}$ \\
\hline \multicolumn{6}{|c|}{ Significance } \\
\hline \multicolumn{2}{|c|}{ TD } & $* * *$ & * & * & ns \\
\hline \multicolumn{2}{|c|}{$\mathrm{TL}$} & $* * *$ & ns & $*$ & ns \\
\hline \multicolumn{2}{|c|}{$\mathrm{TD} \times \mathrm{TL}$} & $* * *$ & $* * *$ & $* * *$ & ns \\
\hline
\end{tabular}

Within each column, mean values followed by different capital letters with regard to main effect (TD, TL) and lowercase letters for interactions (TD $\times \mathrm{TL}$ ), are significantly different at $p \leq 0.05$ according to Tukey's HSD test. Level of significance: ${ }^{*} p \leq 0.05$; ${ }^{* * *} p \leq 0.001$; $\mathrm{ns}-$ not significant. Data are means of four replications $\pm \mathrm{SD}$.

\subsection{Mineral Composition of Fully Mature Broccoli Heads}

The temperature level and the time span of seedling exposure to lower temperatures influenced the mineral composition of the broccoli heads (Table 5). Broccoli cultivated from seedlings treated at $6{ }^{\circ} \mathrm{C}$ for 1 week had the highest content of $\mathrm{P}$ and $\mathrm{Cu}$, more by $10.9 \%$ and $28.2 \%$, respectively, in comparison to the control plants. Treatment of the seedlings at $6{ }^{\circ} \mathrm{C} / 1$ week and $14{ }^{\circ} \mathrm{C} / 1$ week caused significantly higher accumulation of Mn (by $19.3 \%$ and $21.7 \%$, respectively) and $\mathrm{Zn}$ (by $8.8 \%$ and $9.0 \%$, respectively) compared to the control. In the case of $\mathrm{Zn}$, plants treated at $10{ }^{\circ} \mathrm{C} / 2$ weeks also showed a similar increase as aforementioned treatments. Broccoli maintained at $10^{\circ} \mathrm{C} / 2$ weeks had the highest content of $\mathrm{K}$, especially when compared to the control plants and 2-week treatments at $6{ }^{\circ} \mathrm{C}$ and $14{ }^{\circ} \mathrm{C}$. Plants subjected to different temperatures for 1 week contained a similar Mg level in comparison to plants treated with the same temperatures for 2 weeks and to the control plants. Almost all temperature regimes applied at the seedling stage caused an increase in Ca content in broccoli head as compared to the control, with the most spectacular increase noted for plants treated at $6{ }^{\circ} \mathrm{C}$ for 1 week, with a difference of $11.7 \%$. Compared to the 
control, a significantly higher content of Fe was recorded in broccoli treated at $14{ }^{\circ} \mathrm{C}$ for 1 week and $10{ }^{\circ} \mathrm{C}$ for 2 weeks, by $26.5 \%$ and $26.7 \%$, respectively. Plants treated at $14{ }^{\circ} \mathrm{C}$ for 2 weeks often had similar $(\mathrm{P}, \mathrm{K}, \mathrm{Mn}, \mathrm{Zn})$ or lower contents $(\mathrm{Mg}, \mathrm{Ca}, \mathrm{Fe}, \mathrm{Cu})$ of minerals, in comparison with the control.

Exposing seedlings to different durations of low temperature caused changes in mineral composition of broccoli heads. Generally, the highest contents of minerals ( $\mathrm{P}, \mathrm{K}$, $\mathrm{Mg}, \mathrm{Fe}, \mathrm{Cu}, \mathrm{Mn}$, and $\mathrm{Zn}$ ) were recorded in plants chilled at seedling stage for 1 week. Treatments with low temperature for 2 weeks caused an increase in $\mathrm{P}$ and $\mathrm{Zn}$, but a decrease in $\mathrm{Mg}$ when compared to the control broccoli.

Exposure of seedlings to different temperature levels, regardless of the chilling duration, caused changes in minerals levels of broccoli heads. Application of lower temperatures $\left(6,10\right.$, and $\left.14^{\circ} \mathrm{C}\right)$ increased $\mathrm{P}$ and $\mathrm{Zn}$ contents in comparison to the control, plants treated with $10^{\circ} \mathrm{C}$ had more $\mathrm{K}, \mathrm{Fe}$, and, together with $6^{\circ} \mathrm{C}$ treatment, $\mathrm{Cu}$. The lowest temperature applied to the seedlings $\left(6^{\circ} \mathrm{C}\right)$ caused an increase in the Mn content of broccoli heads. No effects of seedling chilling was noted for $\mathrm{Ca}$, though plants treated at $6{ }^{\circ} \mathrm{C}$ had more $\mathrm{Ca}$ than those exposed to $14{ }^{\circ} \mathrm{C}$. Furthermore, $10^{\circ} \mathrm{C}$ caused an increase in $\mathrm{Mg}$ level in broccoli heads in comparison to plants treated with $14^{\circ} \mathrm{C}$.

\subsection{Relationships among Quality Parameters of Seedlings and Fully Mature Broccoli Heads}

The selected quality parameters of broccoli seedlings and heads were analyzed by correlation and regression analysis, including the content of dry weight, soluble sugars, L-ascorbic acid, chlorophyll $a$ and $b$, and carotenoids. No significant relationships were found for chlorophyll pigments and carotenoids in the seedling and in the broccoli heads. It also turned out that linear correlations between the parameters of seedlings and broccoli heads occurred after splitting the data into two groups: the plants treated at seedling stage with lower temperatures for 1 week and for 2 weeks.

Correlations were significant in the case of dry weight, but only for the plants treated with chilling temperatures for 2 weeks (Figure 2a), where $\mathrm{r}=-0.8556(p=0.0004)$. There was no linear relationship between DW of the seedlings and DW of broccoli heads in the case of 1 week treatment $(p=0.2770)$. However, developed regression model showed that the DW content of broccoli heads was significantly dependent $(p<0.001)$ on the content of DW in the seedlings (Figure $2 b$ ), the nature of this relationship was non-linear, and the coefficient of determination was high $\left(R^{2}=0.8012\right)$. The regression equation was developed for predicting DW of broccoli heads (DW-H) on the basis of DW content of the seedlings

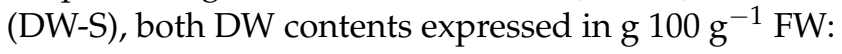

$$
\mathrm{DW}-\mathrm{H}=54.4426705776-8.87788167831 * \mathrm{DW}-\mathrm{S}+0.429256357812 * \mathrm{DW}^{2} \mathrm{~S}^{2}
$$

There were no linear correlations between the content of soluble sugars in the seedlings and in mature broccoli heads (Figure 3a). However, regression analysis proved that a nonlinear relationship between these traits exists (Figure $3 b$ ). The model was statistically significant ( $p=0.003$ ), although the coefficient of determination $R^{2}$ and adjusted coefficient of determination $R^{2}$ adj. were rather low ( 0.4235 and 0.3686 , respectively). Content of soluble sugars in broccoli heads (SS-H) can be approximately calculated from the following equation on the basis of SS content of the seedlings (SS-S), whereby SS contents were expressed as $\mathrm{g} 100 \mathrm{~g}^{-1} \mathrm{FW}$ :

$$
\text { SS-H }=2.62494446261-0.957374013596 * \text { SS-S + } 0.332573773417 * \text { SS}^{2} \text { S }^{2}
$$


Table 5. Effect of low-temperature treatment of the seedlings on macro- and microelement contents of broccoli heads (mg $\left.1000 \mathrm{~g}^{-1} \mathrm{DW}\right)$.

\begin{tabular}{|c|c|c|c|c|c|c|c|c|c|}
\hline $\begin{array}{c}\text { Temperature } \\
\text { Duration } \\
\text { (Weeks) }\end{array}$ & $\begin{array}{c}\text { Temperature } \\
\text { Level } \\
\left({ }^{\circ} \mathrm{C}\right)\end{array}$ & $\mathbf{P}$ & $\mathbf{K}$ & Mg & $\mathrm{Ca}$ & $\mathrm{Fe}$ & $\mathrm{Cu}$ & Mn & $\mathrm{Zn}$ \\
\hline \multirow[t]{2}{*}{1} & 6 & $5784 \pm 136.8 \mathrm{~d}$ & $29916 \pm 989 \mathrm{ab}$ & $1314 \pm 38.4 \mathrm{~d}$ & $4698 \pm 655.6 \mathrm{~b}$ & $79.65 \pm 2.710 \mathrm{bc}$ & $6.542 \pm 0.4539 \mathrm{~d}$ & $22.25 \pm 0.908 b$ & $62.71 \pm 1.971 \mathrm{c}$ \\
\hline & 14 & $5602 \pm 54.7 \mathrm{~cd}$ & $30877 \pm 79 \mathrm{bc}$ & $1333 \pm 18.2 \mathrm{~d}$ & $4476 \pm 312.8 \mathrm{~b}$ & $101.65 \pm 1.028 \mathrm{~d}$ & $5.542 \pm 0.2097 \mathrm{bc}$ & $22.69 \pm 0.661 b$ & $62.83 \pm 0.365 c$ \\
\hline \multirow[t]{3}{*}{2} & 6 & $5508 \pm 191.6 \mathrm{bc}$ & $29108 \pm 504 a$ & $1206 \pm 14.2 \mathrm{ab}$ & $4372 \pm 33.9 b$ & $75.54 \pm 2.150 \mathrm{~b}$ & $5.438 \pm 0.0798 \mathrm{bc}$ & $20.48 \pm 2.643 \mathrm{ab}$ & $60.04 \pm 0.867 b$ \\
\hline & 10 & $5571 \pm 138.2 \mathrm{~cd}$ & $31287 \pm 452 c$ & $1248 \pm 14.0 \mathrm{bc}$ & $4329 \pm 84.2 b$ & $101.77 \pm 2.100 \mathrm{~d}$ & $5.979 \pm 0.6884 \mathrm{~cd}$ & $20.23 \pm 0.774 \mathrm{ab}$ & $62.73 \pm 0.605 c$ \\
\hline & 14 & $5239 \pm 65.4 \mathrm{ab}$ & $28923 \pm 334 a$ & $1159 \pm 17.4 \mathrm{a}$ & $3606 \pm 143.0 \mathrm{a}$ & $61.40 \pm 2.312 \mathrm{a}$ & $4.625 \pm 0.1443 a$ & $18.79 \pm 0.689 a$ & $56.95 \pm 0.313 a$ \\
\hline \multicolumn{10}{|c|}{ Duration (TD) (weeks) } \\
\hline & & $5616 \pm 172.3 \mathrm{C}$ & $30482 \pm 727 \mathrm{~B}$ & $1323 \pm 25.1 \mathrm{C}$ & $4485 \pm 422.3 \mathrm{~B}$ & $88.00 \pm 10.498 \mathrm{~B}$ & $5.882 \pm 0.5556 \mathrm{~B}$ & $21.78 \pm 1.312 \mathrm{~B}$ & $61.67 \pm 2.152 \mathrm{C}$ \\
\hline & & $5439 \pm 197.6 \mathrm{~B}$ & $29773 \pm 1188 \mathrm{~A}$ & $1204 \pm 40.6 \mathrm{~A}$ & $4102 \pm 377.4 \mathrm{~A}$ & $79.57 \pm 17.583 \mathrm{~A}$ & $5.347 \pm 0.6890 \mathrm{~A}$ & $19.83 \pm 1.673 \mathrm{~A}$ & $59.91 \pm 2.534 \mathrm{~B}$ \\
\hline & & $5214 \pm 41.5 \mathrm{~A}$ & $29421 \pm 167 \mathrm{~A}$ & $1290 \pm 20.4 \mathrm{~B}$ & $4208 \pm 153.5 \mathrm{AB}$ & $80.33 \pm 5.001 \mathrm{~A}$ & $5.104 \pm 0.1577 \mathrm{~A}$ & $18.65 \pm 1.710 \mathrm{~A}$ & $57.65 \pm 0.733 \mathrm{~A}$ \\
\hline \multicolumn{10}{|c|}{ Temperature $(\mathrm{TL})\left({ }^{\circ} \mathrm{C}\right)$} \\
\hline & & $5646 \pm 213.3 \mathrm{C}$ & $29512 \pm 845 \mathrm{~A}$ & $1260 \pm 63.8 \mathrm{AB}$ & $4535 \pm 463.7 \mathrm{~B}$ & $77.60 \pm 3.153 \mathrm{~A}$ & $5.990 \pm 0.6628 \mathrm{~B}$ & $21.37 \pm 2.060 \mathrm{~B}$ & $61.38 \pm 2.006 \mathrm{~B}$ \\
\hline & & $5516 \pm 137.6 \mathrm{BC}$ & $30970 \pm 567 \mathrm{~B}$ & $1285 \pm 42.1 \mathrm{~B}$ & $4306 \pm 91.6 \mathrm{AB}$ & $92.24 \pm 10.630 \mathrm{~B}$ & $5.771 \pm 0.5074 \mathrm{~B}$ & $20.32 \pm 0.858 \mathrm{AB}$ & $61.11 \pm 2.144 \mathrm{~B}$ \\
\hline & & $5421 \pm 202.0 \mathrm{~B}$ & $29900 \pm 1068 \mathrm{~A}$ & $1246 \pm 94.3 \mathrm{~A}$ & $4041 \pm 516.6 \mathrm{~A}$ & $81.53 \pm 21.578 \mathrm{~A}$ & $5.084 \pm 0.5180 \mathrm{~A}$ & $20.74 \pm 2.174 \mathrm{AB}$ & $59.89 \pm 3.163 \mathrm{~B}$ \\
\hline \multicolumn{10}{|c|}{ Significance } \\
\hline & & $* * *$ & ** & $* * *$ & * & $* * *$ & ** & $* *$ & $* * *$ \\
\hline & & $* * *$ & $* * *$ & $* *$ & * & $* * *$ & $* * *$ & * & $* * *$ \\
\hline $\mathrm{TD}$ & $\mathrm{TL}$ & $* * *$ & $* * *$ & $* * *$ & $* * *$ & $* * *$ & $* * *$ & $* *$ & $* * *$ \\
\hline
\end{tabular}

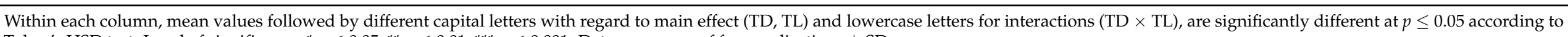
Tukey's HSD test. Level of significance: ${ }^{*} p \leq 0.05 ;{ }^{* *} p \leq 0.01 ;{ }^{* * *} p \leq 0.001$. Data are means of four replications $\pm \mathrm{SD}$. 

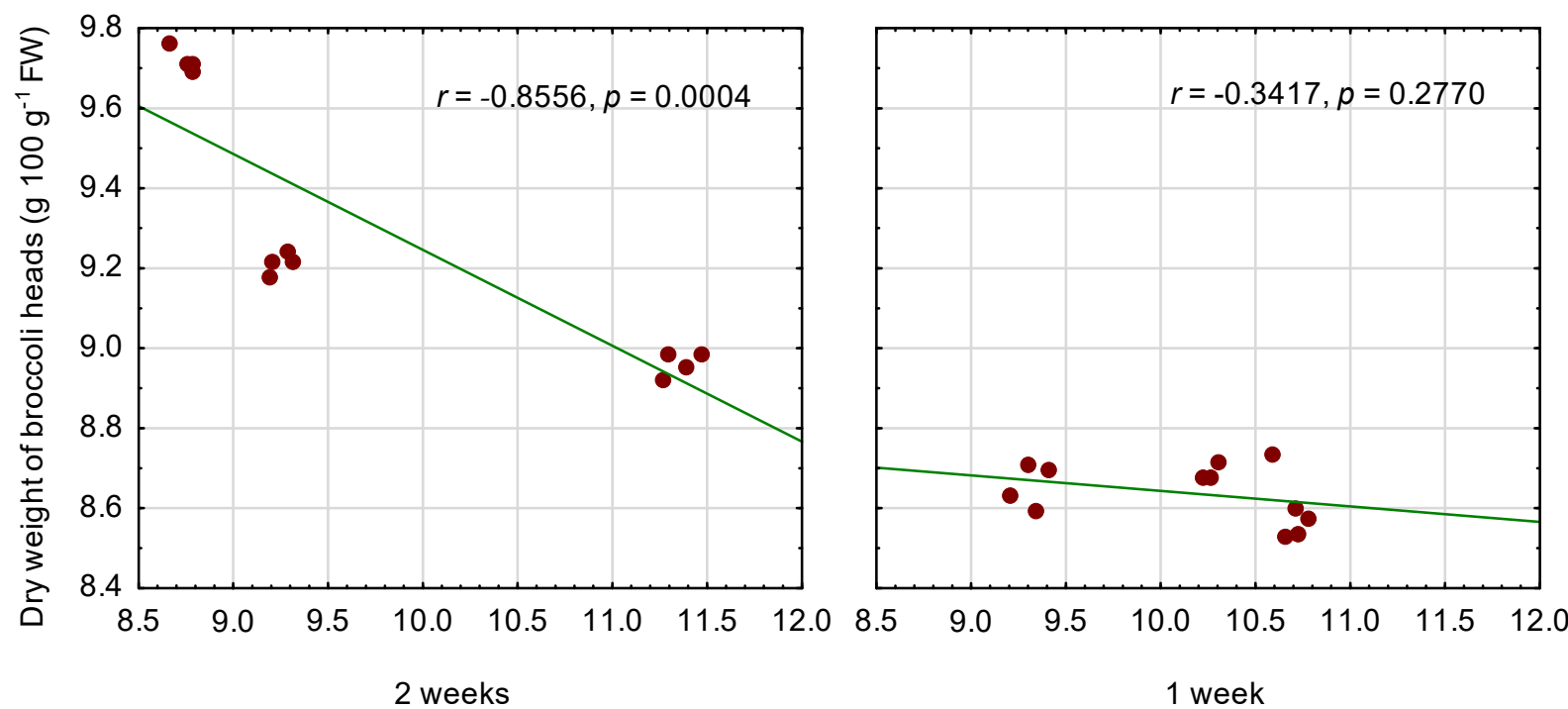

Dry weight of broccoli seedlings (g $\left.100 \mathrm{~g}^{-1} \mathrm{FW}\right)$

(a)

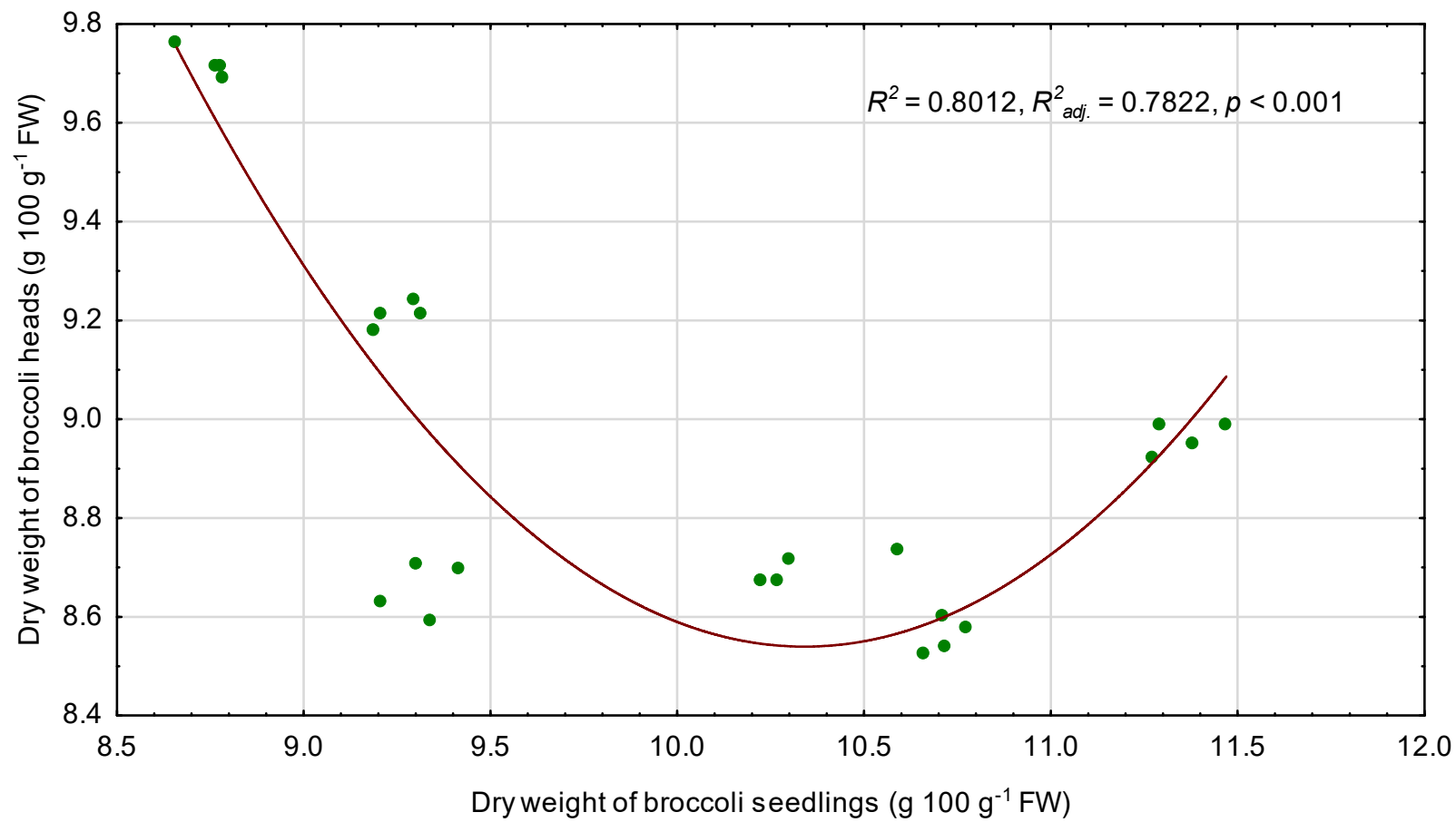

(b)

Figure 2. Linear relationship between dry weight (DW) of broccoli seedlings and DW content of fully mature broccoli heads, separately for temperature duration (a), and polynomial regression model for DW content of broccoli heads depending on the DW content of the seedlings (b). $r$-Pearson correlation coefficient, $R^{2}$ —coefficient of determination, $R^{2}{ }_{a d j}$. - adjusted coefficient of determination, $p$ - probability level. 

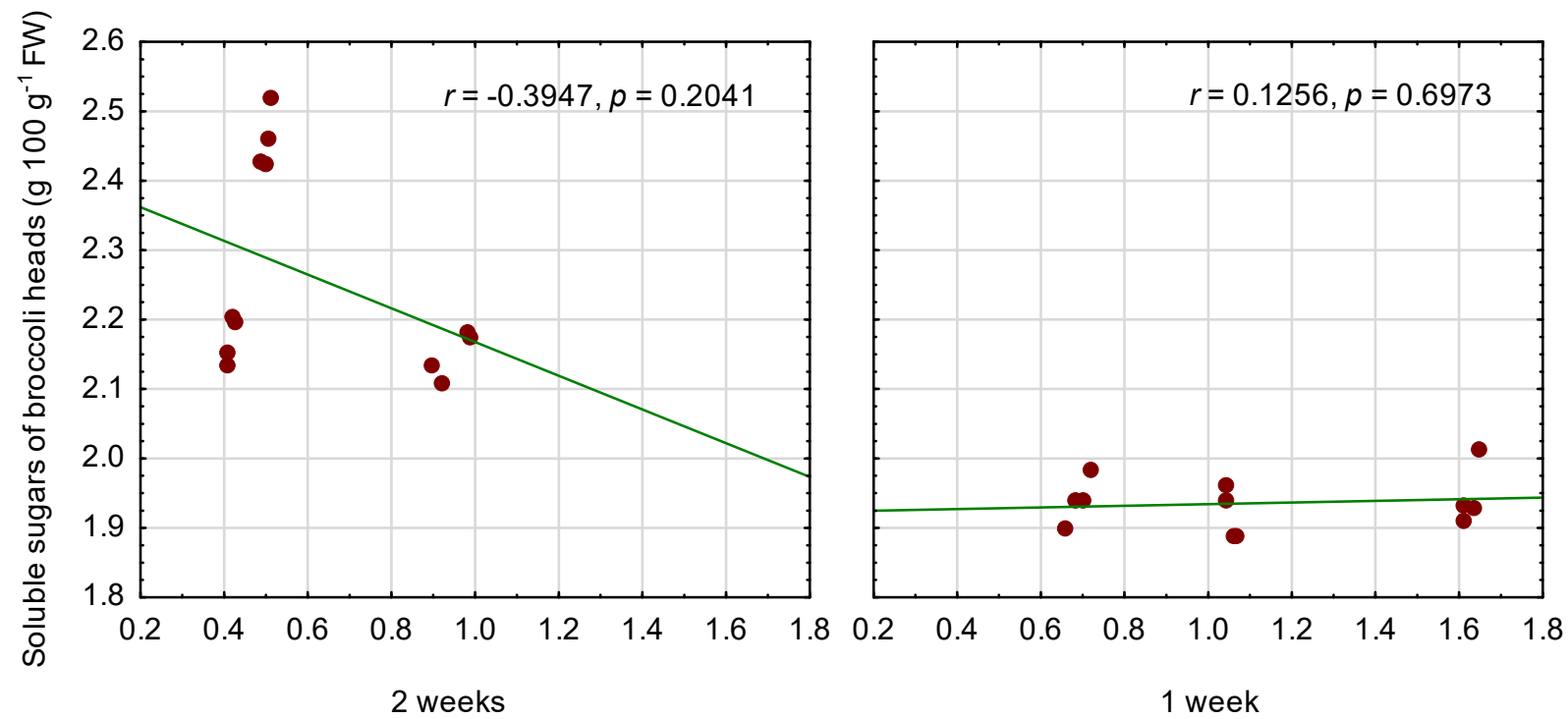

Soluble sugars of broccoli seedlings (g $\left.100 \mathrm{~g}^{-1} \mathrm{FW}\right)$

(a)

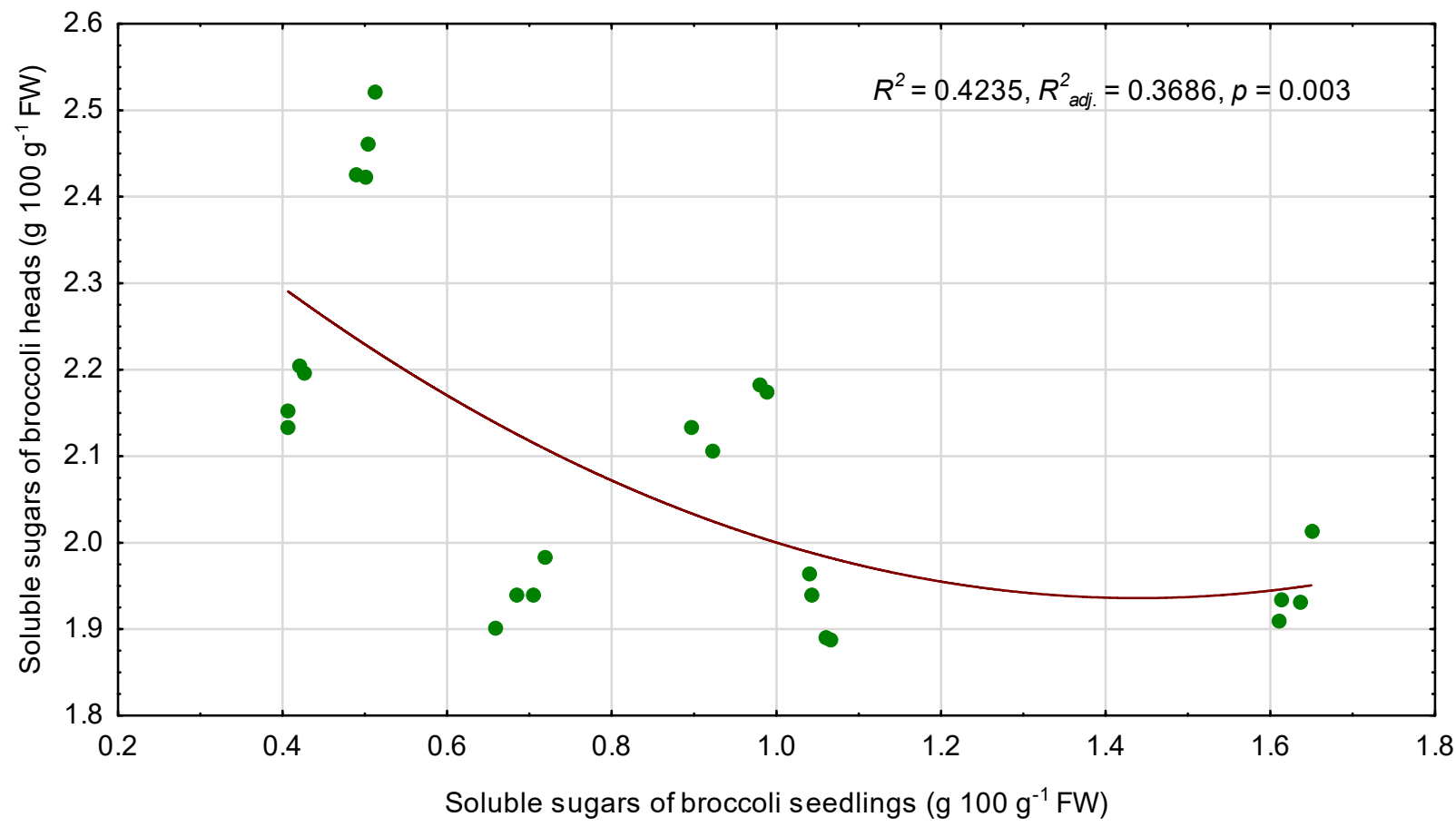

(b)

Figure 3. Linear relationship between soluble sugars (SS) of broccoli seedlings and SS content of fully mature broccoli heads, separately for temperature duration (a), and polynomial regression model for SS content of broccoli heads depending on the SS content of the seedlings (b). $r$-Pearson correlation coefficient, $R^{2}$ —coefficient of determination, $R^{2}$ adj —adjusted coefficient of determination, $p$-probability level.

There were significant and negative correlations between L-ascorbic acid content in the seedlings and in mature broccoli heads (Figure 4a). Plants chilled for 2 weeks had a very high linear correlation coefficient $(r=-0.9840)$. Similarly high, though slightly lower $(\mathrm{r}=-0.8905)$, was noted for plants associated to 1-week treatment. A regression model for predicting L-ascorbic acid in broccoli heads (AsA-H) on the basis of content of this compound in the seedlings (AsA-S) was significant $(p<0.001)$, but $R^{2}$ and $R^{2}$ adj. were 
relatively low ( 0.5873 and 0.5480 , respectively) (Figure $4 \mathrm{~b})$. An approximate content of L-ascorbic acid in broccoli heads can be obtained using a regression equation (contents were expressed in $\mathrm{mg} 100 \mathrm{~g}^{-1} \mathrm{FW}$ ):

$$
\text { AsA-H }=89.2869611715-0.766802210614 * \text { AsA-S }+0.00358044157494 * \text { AsA-S }{ }^{2}
$$

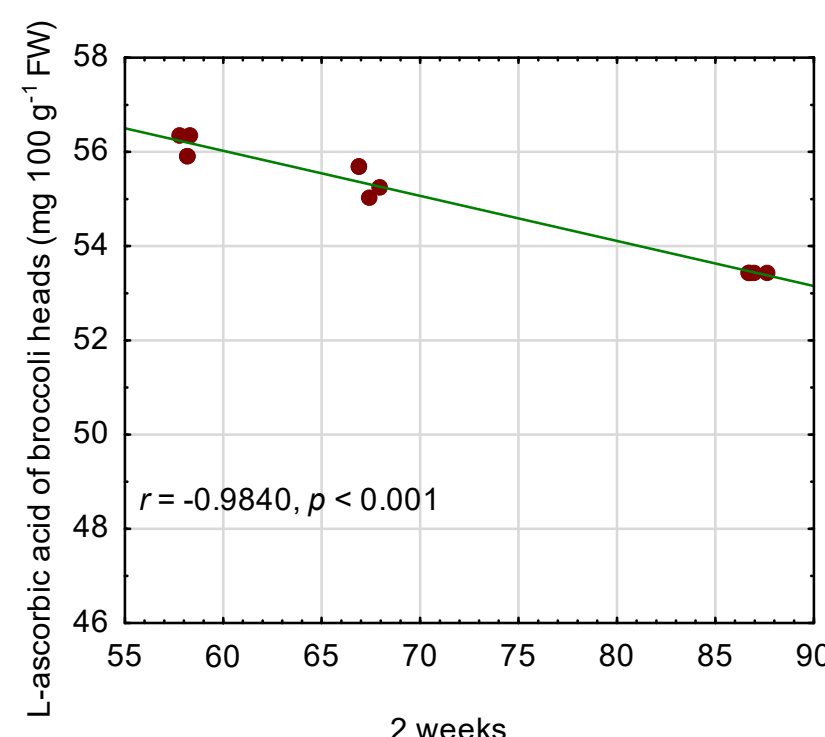

2 weeks

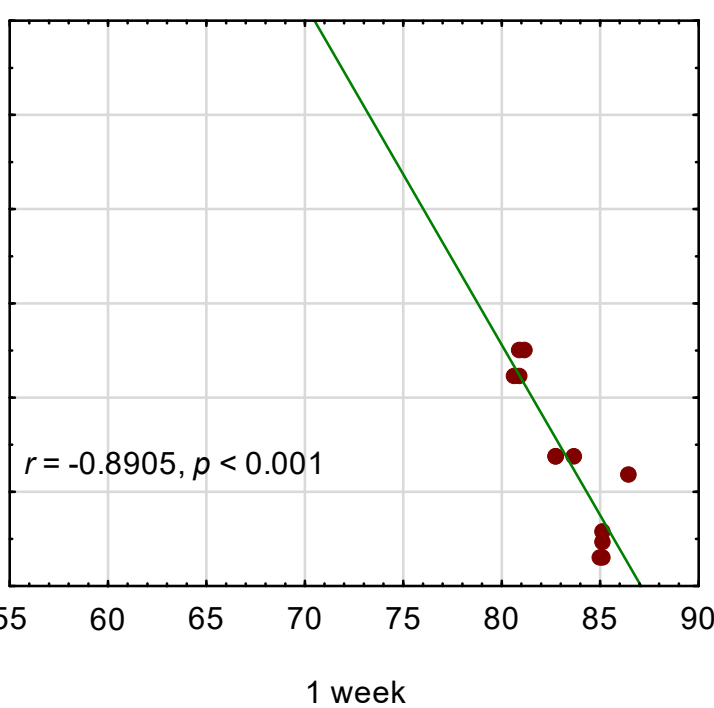

1 week

$\mathrm{L}$-ascorbic acid of broccoli seedlings ( $\mathrm{mg} 100 \mathrm{~g}^{-1} \mathrm{FW}$ )

(a)

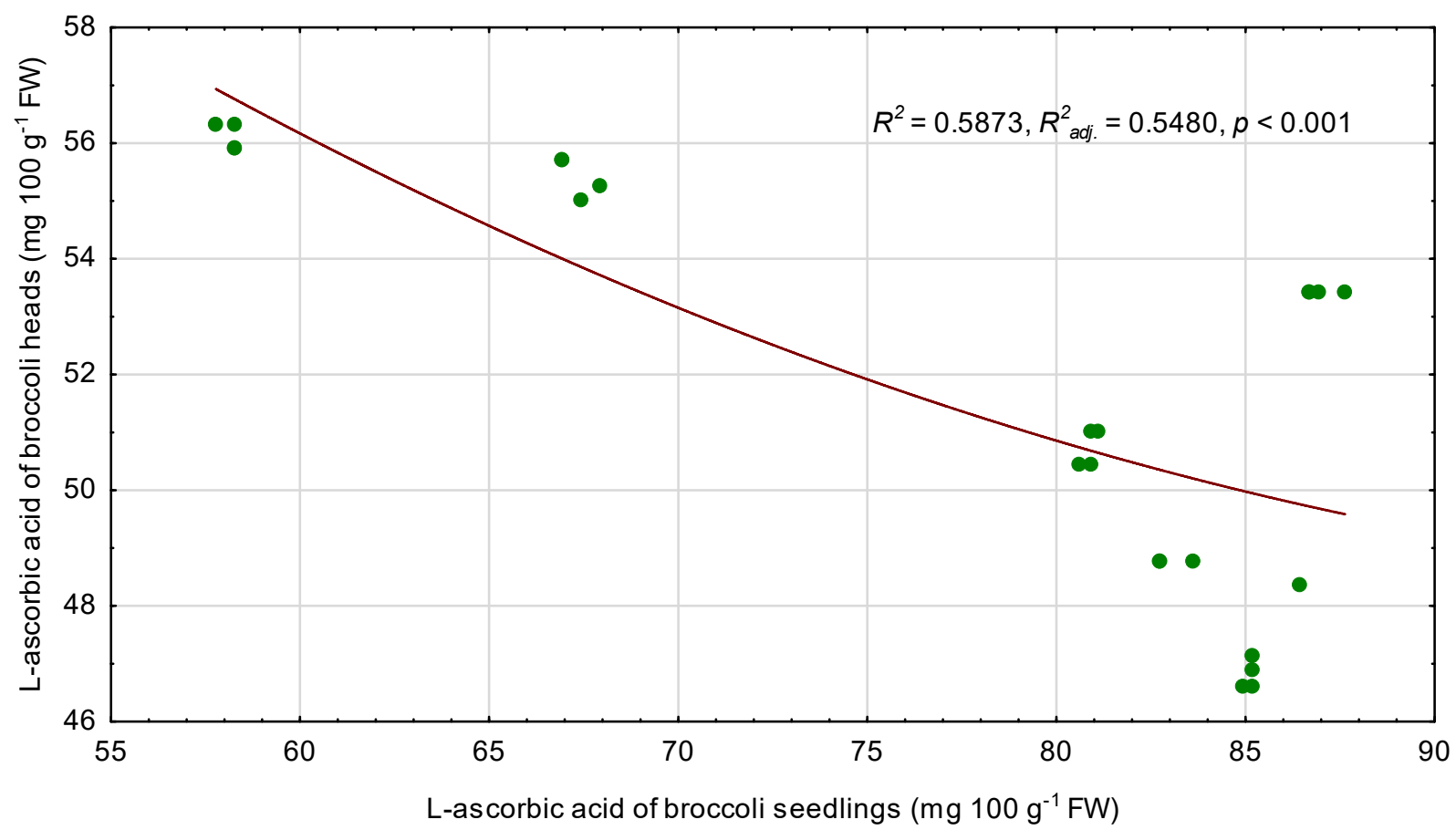

(b)

Figure 4. Linear relationship between L-ascorbic acid (AsA) of broccoli seedlings and AsA content of fully mature broccoli heads, separately for temperature duration (a), and polynomial regression model for AsA content of broccoli heads depending on the AsA content of the seedlings (b). $r$-Pearson correlation coefficient, $R^{2}$ — coefficient of determination, $R^{2}$ adj.-adjusted coefficient of determination, $p$ - probability level. 


\section{Discussion}

\subsection{Broccoli Seedlings Morphological Traits and Chemical Composition as Affected by Chilling}

Broccoli seedlings exhibited a series of morphological changes due to different levels of lowered temperature and different time spans of its exposition. The chilling treatments resulted primarily in the reduction in the seedling height and leaf parameters (number, area, perimeter, and width). Juvenile plants also showed a decrease in fresh and dry weights of shoots and roots. It is well known that exposure of plants to low temperatures hampers their growth via thermodynamically decline of the kinetics of several physiological and metabolic processes [26,27]. A decrease in seedling height and leaf area as well as slower leaf development was observed by Kalisz et al. [28] for Chinese cabbage. Furthermore, Rodríguez et al. [29] noted that plants grown under chilling conditions developed smaller leaves than those grown under control; there was no effect of temperature in the leaf shape of the cabbage, whereas the leaves of the kale developed under thermal stress reacted more by increasing length than width. In our experiment, seedling fresh and dry weights were significantly affected by stressful temperature treatments. The slower growth rate of chilled seedlings resulted in the production of a lower fresh weight of shoots and roots in comparison to the control ones. Rodríguez et al. [29] reported a strong reduction in fresh weight of cabbage and kale by $50 \%$, compared to values observed under control temperature. We observed notable decrease in total dry weight of shoots and roots. Low temperature can affect dry weight production through its limiting effects on the photosynthetic capacity, size of the leaves, and leaf expansion. Moreover, at chilling temperatures, shoot growth processes may be limited by a decreased amount of assimilates, and root water uptake is reduced because of decreased transmembrane transport [30,31]. We observed a significant reduction in the shoot water content in plants grown under $6{ }^{\circ} \mathrm{C}$ as compared to the control plants, which indicate some difficulties in water uptake and conducting water from roots to shoots (see also [32]). However, when chilling temperature were maintained at $10^{\circ} \mathrm{C}$ and $14{ }^{\circ} \mathrm{C}$, a decrease in the percentage of dry weight was noticed, which proves that seedlings contained more water than the control plants grown in $18^{\circ} \mathrm{C}$. In a previous study [28], Chinese cabbage seedlings produced in unheated greenhouse also had a lower percentage of dry weight in comparison with the control plants.

Chilling may result in cellular dehydration [32] and plants react by biosynthesizing osmolytes, such as proline or soluble sugars (SS), which adjust osmotic potential [33]. Plants under stress increase soluble sugars concentration compared to non-stressed plants [34], which reduce osmotic potential and improve stress tolerance [32]. Measurements of soluble sugars concentration in broccoli seedlings showed that values were significantly higher in plants treated with $6^{\circ} \mathrm{C}$ (especially after 1 week of exposure); however, SS content in seedlings treated with $10^{\circ} \mathrm{C}$ and $14^{\circ} \mathrm{C}$ was generally lower in comparison to the control. The lowest temperature applied turned out to be the strongest stimulus for the synthesis of sugars; although, after 2 weeks of chilling, some stabilization in this regard was visible and the sugars content was comparable to their amount in the control plants.

Chilling stress exacerbates reactive oxygen species (ROS) production in plants' cell. Excess production and the accumulation of ROS causes oxidative stress that leads to disruption of cellular membranes, enzymes inactivation, lipid peroxidation, protein degradation, and ionic imbalance in plants [8,10]. Efficient scavenging of ROS requires the action of several nonenzymatic antioxidants including ascorbic acid (AsA). Thus, we expected higher levels of L-ascorbic acid in chilled plants, though it turned out that the plants treated with lowered temperatures generally had a lower concentration of AsA than the control seedlings. Because the purpose of this study was not to delve into the action of antioxidant mechanisms, it can only be assumed that the role of scavengers was taken over by other antioxidant compounds, or plants have already used AsA to cope with the oxidative stress.

\subsection{Broccoli Heads Chemical Composition as Affected by Seedlings Chilling}

In our research, it turned out that exposing broccoli seedlings to different temperature and for different time periods caused long-term effects, which reflected in the alteration of 
chemical composition of mature heads. The short-term exposure of plants to chilling may alter metabolic pathways and physiological processes, and cause changes at the molecular level and finally in the growth $[8,10,32,35]$. Metabolic modulation after plant exposure to chilling leads to acclimatization processes and primed state that may persist until a subsequent exposure [35,36]. Sometimes stress-induced modifications revert to the initial level once the stress factor is removed, though some alterations in plant metabolism are stable, more long-lasting, and can be visible even after several days or weeks, implying that plants have some type of stress memory $[37,38]$. However, in many cases, such a stress memory is not established, but the reasons for this are poorly understood. There is also a significant gap in our understanding of stress memory length and dissipation mechanisms [36]. Our research confirmed the stress memory induction as chilled plants formed heads containing more L-ascorbic acid $\left(6,10\right.$ and $\left.14{ }^{\circ} \mathrm{C}\right)$, dry weight (10 and $\left.14^{\circ} \mathrm{C}\right)$, and soluble sugars $\left(14^{\circ} \mathrm{C}\right)$. An interesting fact is that seedling chilling did not affect chlorophylls and carotenoids concentrations in mature broccoli heads.

L-ascorbic acid belongs to the group of main non-enzymatic antioxidants that play a vital role in the mitigation of excessive ROS activity as well as in ROS detoxification $[10,39,40]$. Some reports on chilling stress described higher levels of AsA in plants treated with low temperature [41]. As we noted, both 1 and 2 weeks of chilling did not increase the concentration of L-ascorbic acid in the seedlings, and, in this respect, a possible explanation was mentioned above, though it seems that stress predisposed plants to a more intensive synthesis of L-ascorbic acid in further stages of ontogeny, which resulted in increased levels observed during broccoli harvesting. This assumption is confirmed by the results of the correlation analysis and the developed regression model for AsA. Taking these results into account, an interesting fact was observed, namely the lower content of L-ascorbic acid in the seedlings was associated with its greater amount in mature broccoli heads.

The percentage of dry weight and soluble sugars in fresh weight of broccoli heads was significantly higher when seedlings were subjected to 10 and $14{ }^{\circ} \mathrm{C}$ or $14{ }^{\circ} \mathrm{C}$, respectively. It seems, however, that these parameters will not necessarily be very important biomarkers of stress, taking into account relatively small differences in the obtained values, although statistically confirmed. However, it is visible on the basis of the regression models obtained that the relationship between the dry weight or soluble sugars ( $100 \mathrm{~g}^{-1} \mathrm{FW}$ ) content in seedlings and its content in broccoli heads exists and is non-linear.

Manifestation of stress memory possibly modified plant growth and metabolism, altering the uptake, distribution, and accumulation of chemical elements. In previous studies, we observed that chilling of cauliflower juvenile plants resulted in increased concentrations of $\mathrm{N}, \mathrm{P}, \mathrm{Ca}, \mathrm{S}, \mathrm{Mg}, \mathrm{Na}, \mathrm{B}, \mathrm{Cu}, \mathrm{Zn}, \mathrm{Pb}, \mathrm{Ag}, \mathrm{Ba}, \mathrm{Co}, \mathrm{Sc}, \mathrm{Sr}$, and $\mathrm{Tb}$, and decreased $\mathrm{Mo}, \mathrm{Cr}$, and $Y$ contents of mature curds [18,19]. Furthermore, Sękara et al. [42] proved that chilling of seedlings affects the levels of mineral nutrients in the fruits of previously stressed eggplants. Therefore, we proved that the application of the stress factor of plant seedling may result in changes in the content of elements in edible plant parts, but the mechanism by which the accumulation of elements is changed still requires additional research. We observed that application of a particular level of lower temperature to the seedlings may increase $\mathrm{P}$, $\mathrm{K}, \mathrm{Fe}, \mathrm{Cu}, \mathrm{Mn}$, and $\mathrm{Zn}$ contents in the heads of broccoli in comparison to the control. In another study [43], it was shown that temperature stress slowed the initial growth of the broccoli plants in the field compared to the non-chilled control, but later their development was accelerated. The reason for the higher level of minerals in chilled broccoli observed in present study may be the higher plant growth pace, which means a greater demand for mineral elements and accordingly a higher absorption amount. However, uptake processes are important but maintaining primed state by plants requires the allocation of resources [38] which can be different due to chilling treatment. Thus, the concentration of particular elements in edible parts of the chilled and non-chilled plants may be a result of diverse growth pace and nutrient demand [18], alteration in root morphology or in uptake and distribution of elements in the tissues [44,45], and synergism and antagonism between 
them [46], but involvement of elements in acclimatization processes and keeping primed state $[47,48]$ should also be taken into consideration.

\subsection{Relationships between the Seedling Traits and the Chemical Composition of Fully Mature Broccoli Heads}

We presented an insight into linking some broccoli seedling traits with those of already mature plants. The quality of seedlings influences further growth and development of crops and plays an important role in the final condition of plants $[42,49,50]$. In this context, controlled abiotic stress applied at the seedling stage can be used as a tool for inducing stress memory, which leads to modification of plant metabolic pathways and altering the level of several phytochemicals, potentially having an impact on the nutraceutical value of the yield [36-38]. The search for biomarkers that will testify the existence of a stress memory is ongoing, but it is a difficult task, especially when it involves the traits of juvenile plants and the traits of fully mature plants grown in the field. Plant modeling is a way to synthesize and simplify complex interactions throughout the plant life cycle to obtain information about the most relevant target traits of juvenile plants that can be considered as stress markers, which alteration can be noticeable in mature plants. The existence of such relationships has already been preliminary examined for some vegetable species, including cauliflower and broccoli $[16,18,19,43,51]$. In previous study, we have presented the long-term effects of seedling chilling on subsequent broccoli development in the field and its yield [43]. More specifically, we tracked changes in fresh weight (FW), dry weight (DW), and chosen leaf parameters that were measured from $21^{\text {st }}$ day after planting the plants to the field and for the next 40 days. It was found that chilling finally increased (after two months) both the FW and DW of broccoli, particularly when $6{ }^{\circ} \mathrm{C}$ for 1 week (FW) and $14{ }^{\circ} \mathrm{C}$ for 1 week (FW and DW) were applied, while the leaf area and leaf perimeter were significantly influenced by chilling only one month after planting. The present study followed up that experiment, and we focused on the characteristics of plants at two other time points: just before planting and during harvest, looking for biomarkers in chosen phytochemicals. The obtained results indicate that the role of such a biomarker may be referred to L-ascorbic acid, although a negative correlation between the content of this compound in the broccoli seedlings and in the harvested mature heads was unexpected (Figure 4a). Dry weight content can also be an indicator of plant stress exposure, but in this case the relationship was not linear (Figure 2b). However, the regression model obtained for DW was characterized by a high R-squared value and it fits the observed data in $80 \%$.

\section{Conclusions}

Based on the results obtained, we can conclude that chilling treatment of broccoli seedlings significantly influence juvenile plant fresh weight and its morphology, content of dry weight, soluble sugars, and L-ascorbic acid. Long-term effects of seedling chilling involved the alteration of dry weight, soluble sugars, and L-ascorbic acid contents in broccoli heads, but with no influence on chlorophylls and carotenoids accumulation. This study also demonstrated variability in the accumulation of the assessed elements in broccoli heads resulted from diverse pace of growth and nutrient demand of chilled and non-chilled plants. The relationship between L-ascorbic acids content in seedlings and in mature broccoli heads suggests that it can be perceived as a stress biomarker.

Author Contributions: Conceptualization, A.K. and J.G.; methodology, A.K. and E.K.; formal analysis, J.G.; investigation, J.G. and A.K.; writing-original draft preparation, J.G. and A.K; writing-review and editing, A.K., A.S. (Agnieszka Sẹkara), E.K., A.S. (Andrzej Sałata) and G.C.; visualization, J.G. and A.K.; supervision, A.K.; funding acquisition, A.K. All authors have read and agreed to the published version of the manuscript.

Funding: This research was funded by Polish Ministry of Science and Higher Education, grant number N N310 305239.

Institutional Review Board Statement: Not applicable. 
Informed Consent Statement: Not applicable.

Data Availability Statement: Most data supporting the results are included in the article. The datasets used and/or analyzed during the current study are available from the corresponding author on reasonable request.

Conflicts of Interest: The authors declare no conflict of interest.

\section{References}

1. Moreno, D.A.; López-Berenguer, C.; Carvajal, M.; García-Viguera, C. Health benefits of broccoli. Influence of pre- and post-harvest factors on bioactive compounds. Food 2007, 1, 297-312.

2. Podsędek, A. Natural antioxidants and antioxidant capacity of Brassica vegetables: A review. LWT Food Sci. Technol. 2007, 40, 1-11. [CrossRef]

3. Valverde, J.; Reilly, K.; Villacreces, S.; Gaffney, M.; Grant, J.; Brunton, N. Variation in bioactive content in broccoli (Brassica oleracea var. italica) grown under conventional and organic production systems. J. Sci. Food Agric. 2015, 95, 1163-1171. [CrossRef]

4. Pathare, P.B.; Mohapatra, D. Bioactive compounds in broccoli: Extraction and processing. In Vegetable Processing and Bioactive Compounds; Kadam, D.M., Sharma, M., Kaur, D., Eds.; Studium Press (India) Pvt. Ltd.: New Delhi, India, 2017 ; pp. 420-450.

5. Nuñez-Gómez, V.; Baenas, N.; Navarro-González, I.; García-Alonso, J.; Moreno, D.A.; González-Barrio, R.; Periago-Castón, M.J. Seasonal variation of health-promoting bioactives in broccoli and methyl-jasmonate pre-harvest treatments to enhance their contents. Foods 2020, 9, 1371. [CrossRef]

6. Jahangir, M.; Kim, H.K.; Choi, Y.H.; Verpoorte, R. Health-affecting compounds in Brassicaceae. Compr. Rev. Food Sci. Food Saf. 2009, 8, 31-43. [CrossRef]

7. Zhao, X.Q.; Wang, W.S.; Zhang, F.; Zhang, T.; Zhao, W.; Fu, B.-Y.; Li, Z.-K. Temporal profiling of primary metabolites under chilling stress and its association with seedling chilling tolerance of rice (Oryza sativa L.). Rice 2013, 6, 23. [CrossRef] [PubMed]

8. Huang, H.; Ullah, F.; Zhou, D.-X.; Yi, M.; Zhao, Y. Mechanisms of ROS regulation of plant development and stress responses. Front. Plant Sci. 2019, 10, 800. [CrossRef] [PubMed]

9. Mittler, R.; Vanderauwera, S.; Gollery, M.; Van Breusegem, F. Reactive oxygen gene network of plants. Trends Plant Sci. 2004, 9, 490-498. [CrossRef]

10. Sharma, P.; Jha, A.B.; Dubey, R.S.; Pessarakli, M. Reactive oxygen species, oxidative damage, and antioxidative defense mechanism in plants under stressful conditions. J. Bot. 2012, 2012, 217037. [CrossRef]

11. Hasanuzzaman, M.; Bhuyan, M.; Zulfiqar, F.; Raza, A.; Mohsin, S.M.; Mahmud, J.A.; Fujita, M.; Fotopoulos, V. Reactive oxygen species and antioxidant defense in plants under abiotic stress: Revisiting the crucial role of a universal defense regulator. Antioxidants 2020, 9, 681. [CrossRef] [PubMed]

12. Rivero, R.M.; Ruiz, J.M.; García, P.C.; López-Lefebre, L.R.; Sánchez, E.; Romero, R. Resistance to cold and heat stress: Accumulation of phenolic compounds in tomato and watermelon plants. Plant Sci. 2001, 160, 315-321. [CrossRef]

13. Sivaci, A.; Kaya, A.; Duman, S. Effects of ascorbic acid on some physiological changes of pepino (Solanum muricatum Ait.) under chilling stress. Acta Biol. Hung. 2014, 65, 305-318. [CrossRef]

14. Sasaki, H.; Ichimura, K.; Imada, S.; Hamaki, S. Sucrose synthase and sucrosephosphate synthase, but not acid invertase, are regulated by cold acclimation and deacclimation in cabbage seedlings. J. Plant Physiol. 2001, 158, 847-852. [CrossRef]

15. Gao, Q.H.; Xu, K.; Wang, X.F.; Wu, Y. Effect of grafting on cold tolerance in eggplant seedlings. Acta Hortic. 2008, 771, 167-174. [CrossRef]

16. Długosz-Grochowska, O.; Leja, M.; Grabowska, A.; Kunicki, E. The effect of preliminary chilling of broccoli transplants on some antioxidative parameters. Folia Hort. 2012, 24, 131-139.

17. Javanmardi, J.; Rahem, M.; Nasirzadeh, M. Physiological and reproductive responses of tomato and pepper transplants to low-temperature conditioning. Int. J. Veg. Sci. 2013, 19, 294-310. [CrossRef]

18. Kalisz, A.; Sẹkara, A.; Smoleń, S.; Grabowska, A.; Gil, J.; Cebula, S. Mineral composition of cauliflowers with differently coloured curds modified by the chilling of juvenile plants. Sci. Hortic. 2018, 232, 216-225. [CrossRef]

19. Kalisz, A.; Sękara, A.; Smoleń, S.; Grabowska, A.; Gil, J.; Komorowska, M.; Kunicki, E. Survey of 17 elements, including rare earth elements, in chilled and non-chilled cauliflower cultivars. Sci. Rep. 2019, 9, 5416. [CrossRef]

20. FAO. World Reference Base for Soil Resources; FAO: Rome, Italy, 2014.

21. Grabowska, A.; Kunicki, E. Brokuty od Wiosny do Jesieni [Broccoli from Spring to Fall]; Planpress: Kraków, Poland, 2013.

22. Yemm, E.W.; Willis, A.J. The estimation of carbohydrates in plant extracts by anthrone. Biochem. J. 1954, 57, 508-514. [CrossRef] [PubMed]

23. Krełowska-Kułas, M. Badanie jakości produktów spożywczych. In The Study of Food Quality; PWN: Warszawa, Poland, 1993.

24. Lichtenthaler, H.K.; Wellburn, A.R. Determinations of total carotenoids and chlorophylls a and b of leaf extracts in different solvents. Biochem. Soc. Trans. 1983, 603, 591-592. [CrossRef]

25. Ostrowska, A.; Gawliński, S.; Szczubiałka, Z. Metody Analizy i Oceny Właściwości Gleb i Roślin [The Methods of Analysis and Estimation of Soils and Plants Properties]; Instytut Ochrony Środowiska: Warszawa, Poland, 1991.

26. Ruelland, E.; Vaultier, M.N.; Zachowski, A.; Hurry, V. Cold signalling and cold acclimation in plants. Adv. Bot. Res. 2009, 49, 35-150. 
27. Hussain, S.; Khan, F.; Cao, W.; Wu, L.; Geng, M. Seed priming alters the production and detoxification of reactive oxygen intermediates in rice seedlings grown under sub-optimal temperature and nutrient supply. Front. Plant Sci. 2016, 7, 439. [CrossRef] [PubMed]

28. Kalisz, A.; Cebula, S. The effect of temperature on growth and chemical composition of Chinese cabbage seedlings in spring period. Folia Hort. 2006, 18, 3-15.

29. Rodríguez, V.M.; Soengas, P.; Alonso-Villaverde, V.; Sotelo, T.; Cartea, M.E.; Velasco, P. Effect of temperature stress on the early vegetative development of Brassica oleracea L. BMC Plant Biol. 2015, 15, 145. [CrossRef] [PubMed]

30. Verheul, M.J.; Picatto, C.; Stamp, P. Growth and development of maize (Zea mays L.) seedlings under chilling conditions in the field. Eur. J. Agron. 1996, 5, 31-43. [CrossRef]

31. Poiré, R.; Schneider, H.; Thorpe, M.R.; Kuhn, A.J.; Schurr, U.; Walter, A. Root cooling strongly affects diel leaf growth dynamics, water and carbohydrate relations in Ricinus communis. Plant Cell Environ. 2010, 33, 408-417. [CrossRef] [PubMed]

32. Hussain, H.A.; Hussain, S.; Khaliq, A.; Ashraf, U.; Anjum, S.A.; Men, S.; Wang, L. Chilling and drought stresses in crop plants: Implications, cross talk, and potential management opportunities. Front. Plant Sci. 2018, 9, 393. [CrossRef] [PubMed]

33. Yadav, S.K. Cold stress tolerance mechanisms in plants. A review. Agron. Sust. Dev. 2010, 30, 515-527. [CrossRef]

34. Kumar, S.; Malik, J.; Thakur, P.; Kaistha, S.; Sharma, D.; Upadhyaya, H.D.; Berger, J.D.; Nayyar, H. Growth and metabolic responses of contrasting chickpea (Cicer arietinum) genotypes to chilling stress at reproductive phase. Acta Physiol. Plant. 2011, 33, 779-787. [CrossRef]

35. Nievola, C.C.; Carvalho, C.P.; Carvalho, V.; Rodrigues, E. Rapid responses of plants to temperature changes. Temperature 2017, 4, 371-405. [CrossRef] [PubMed]

36. Crisp, P.A.; Ganguly, D.; Eichten, S.R.; Borevitz, J.O.; Pogson, B.J. Reconsidering plant memory: Intersections between stress recovery, RNA turnover, and epigenetics. Sci. Adv. 2016, 2, e1501340. [CrossRef] [PubMed]

37. Bruce, T.J.A.; Matthes, M.C.; Napier, J.A.; Pickett, J.A. Stressful "memories" of plants: Evidence and possible mechanisms. Plant Sci. 2007, 173, 603-608. [CrossRef]

38. Lämke, J.; Bäurle, I. Epigenetic and chromatin-based mechanisms in environmental stress adaptation and stress memory in plants. Genome Biol. 2017, 18, 124. [CrossRef] [PubMed]

39. Qian, H.F.; Peng, X.F.; Han, X.; Ren, J.; Zhan, K.Y.; Zhu, M. The stress factor, exogenous ascorbic acid, affects plant growth and the antioxidant system in Arabidopsis thaliana. Russ. J. Plant Physiol. 2014, 61, 467-475. [CrossRef]

40. Venkatesh, J.; Park, S.W. Role of L-ascorbate in alleviating abiotic stresses in crop plants. Bot. Stud. 2014, 55, 38. [CrossRef]

41. Duan, M.; Ma, N.N.; Li, D.; Deng, Y.S.; Kong, F.Y.; Lv, W.; Meng, Q.W. Antisense-mediated sup-pression of tomato thylakoidal ascorbate peroxidase influences antioxidant network during chilling stress. Plant Physiol. Biochem. 2012, 58, 37-45. [CrossRef]

42. Sękara, A.; Kalisz, A.; Bączek-Kwinta, R.; Gawęda, M.; Pohl, A.; Grabowska, A. The effect of abiotic stresses applied in the juvenile phase of eggplant ontogeny on chemical composition of seedlings and fruits. Agrochimica 2015, 59, $26-43$.

43. Kalisz, A.; Sękara, A.; Grabowska, A.; Cebula, S.; Kunicki, E. The effect of chilling stress at transplant stage on broccoli development and yield with elements of modeling. J. Plant Growth Regul. 2015, 34, 532-544. [CrossRef]

44. Taşpınar, M.S.; Dumlupinar, R.; Demir, F.; Çakmak, T.; Gülen, Y. Determination of chilling temperature effects on nutrient elements composition and distribution in cole (Brassica oleracea L. cv. acephala) using the WDXRF spectroscopic technique. Afr. J. Biotechnol. 2009, 8, 6569-6575.

45. Hussain, H.A.; Men, S.; Hussain, S.; Zhang, Q.; Ashraf, U.; Anjum, S.A.; Ali, I.; Wang, L. Maize tolerance against drought and chilling stresses varied with root morphology and antioxidative defense system. Plants 2020, 9, 720. [CrossRef]

46. Kabata-Pendias, A. Trace Elements in Soils and Plants, 4th ed.; CRC Press, Taylor and Francis Group: Boca Raton, FL, USA, 2011.

47. Zengin, F.K. The effect of $\mathrm{Co} 2+$ and $\mathrm{Zn} 2+$ on the contents of protein, abscisic acid, proline and chlorophyll in bean (Phaseolus vulgaris cv. Strike) seedlings. J. Environ. Biol. 2006, 27, 441-448. [PubMed]

48. Waraich, E.A.; Ahmad, R.; Halim, A.; Aziz, T. Alleviation of temperature stress by nutrient management in crop plants: A review. J. Soil Sci. Plant Nutr. 2012, 12, 221-244. [CrossRef]

49. Cebula, S. The effect of pot size and transplant age on the yield and quality of white, green and romanesco cauliflower curds. Veg. Crops Res. Bull. 2009, 70, 101-110. [CrossRef]

50. Grabowska, A.; Sękara, A.; Kalisz, A.; Kunicki, E.; Wojciechowska, R.; Kopta, T. Optimisation of transplant age in combination with dark-chilling to enhance the biological quality of broccoli cultivated in summer. Not. Bot. Horti. Agrobot. Cluj Napoca 2018, 46, 494-500. [CrossRef]

51. Kalisz, A.; Sękara, A.; Cebula, S.; Grabowska, A.; Kunicki, E. Impact of low-temperature transplant treatment on yield and quality of cauliflower curds in late spring production. Sci. Hortic. 2014, 176, 134-142. [CrossRef] 